\title{
Overview of Gemstone Resources in China
}

\author{
Xiao-Yan Yu ${ }^{1, *}$, Zheng-Yu Long ${ }^{1}$, Yi Zhang ${ }^{1}$, Li-Jie Qin ${ }^{1}$, Cun Zhang ${ }^{1,2}$, Zhi-Rong Xie ${ }^{1}$, Yu-Rui Wu ${ }^{1}$, Ying Yan ${ }^{1}$, \\ Ming-Ke $\mathrm{Wu}^{1}$ and Jia-Xin Wan ${ }^{1}$
}

1 School of Gemology, China University of Geosciences Beijing, 29 Xueyuan Road, Beijing 100083, China; zhengyulong@email.cugb.edu.cn (Z.-Y.L.); zhangyi0186@163.com (Y.Z.); 2009200043@cugb.edu.cn (L.-J.Q.); geozhangc@163.com (C.Z.); xzr08270916@163.com (Z.-R.X.); wuyr1020@163.com (Y.-R.W.); 2009210031@email.cugb.edu.cn (Y.Y.); 2009210033@email.cugb.edu.cn (M.-K.W.); opwjx1207@163.com (J.-X.W.)

2 School of Materials Science and Engineering, Qilu University of Technology (Shandong Academy of Sciences), Jinan 250353, China

* Correspondence: yuxy@cugb.edu.cn

Citation: Yu, X.-Y.; Long, Z.-Y.; Zhang, Y.; Qin, L.-J.; Zhang, C.; Xie, Z.-R.; Wu, Y.-R.; Yan, Y.; Wu, M.-K.; Wan, J.-X. Overview of Gemstone Resources in China. Crystals 2021, 11, 1189. https://doi.org/10.3390/ cryst11101189

Academic Editors: Tingting Gu, Taijin Lu, Fei Liu and Yuri N. Palyanov

Received: 28 August 2021

Accepted: 24 September 2021

Published: 29 September 2021

Publisher's Note: MDPI stays neutral with regard to jurisdictional claims in published maps and institutional affiliations.

Copyright: (c) 2021 by the authors. Licensee MDPI, Basel, Switzerland. This article is an open access article distributed under the terms and conditions of the Creative Commons Attribution (CC BY) license (https:// creativecommons.org/licenses/by/ $4.0 /)$.

\begin{abstract}
Gemstones are minerals of gem qualities used for adornment and decoration with the attributes of beauty, durability and rarity. Traditionally, although China has been regarded as the most important source for nephrite, over the past decades, a large variety of gemstone resources have been newly discovered in China owing to continuous exploration works. The vast land with various geological and geochemical backgrounds is rich in gemstone resources with potential for new deposits discoveries. In pegmatites, gemstones are related to granitic magma events and mainly occur in pegmatitic cavities, such as tourmaline, aquamarine, spodumene, spessartine, moonstone, quartz, apatite, and topaz. The eruption of Tertiary basaltic magma provides gem-quality sapphire, spinel, olivine, garnet, and zircon. The supergene oxidation zones of some copper and iron deposits in Hubei and Anhui province host gem-quality turquoise and malachite. Moreover, the formation of the nephrite deposit in China is mostly related to the carbonatite and serpentinite rocks involved in the metamorphic-metasomatic processes. This paper comprehensively introduces the distribution of gemstones deposits, as well as the gemological and mineralogical characteristics of gemstones in China. Our present investigation provides insights into the gemstone potential of China for further exploitation.
\end{abstract}

Keywords: gemstones; gemstone deposits; jades; gemology; mineralogy; China

\section{Introduction}

Gems are amongst the rarest and most precious materials on Earth. Throughout history, they have played an indispensable role in economics, politics, religion, lore, and fashion. Gems are materials used for adornment and decoration that must generally have the attributes of beauty, durability, and rarity. Apart from pearls, amber, coral and other organic materials, most gems in the world are single crystals of natural minerals, and a few are rocks, as well as a part of amorphous materials (such as Opal and natural glass) [1,2]. Moreover, in a broader sense, any mineral, stone or material that is beautiful enough to be sought, mined, and sold for its beauty alone can be used as a gemstone based upon Groat [3] and Stern et al. [4]. In detail, the most important gemstones are diamond, ruby, sapphire, chrysoberyl, emerald, jadeite, and nephrite. More common gemstones include silica gems, feldspar, tourmaline, spinel, garnet, olivine, topaz, apatite, etc. Additionally, some special varieties are serpentine jade, Dushan jade, inkstone, and Chinese seal stone, which have been widely regarded as gems by Chinese people. These rocks can be processed into beautiful carvings and thus would be considered as gems in this paper if given the generalization of gem definition above. As proposed by Groat and Laurs [5], it is the characteristics of a specific sample that makes a gemstone rather than the mineral itself. 
Gemstones, as an integral part of the earth's material, are also important objects to explore the compositions, characteristics, and evolution of the Earth. Thus, some gemstones have been considered the pivotal probes for investigating geological information in specific environments, such as diamond, which has acted as the messenger of the mantle (e.g., [6,7]). More importantly, gems are different from common minerals and rocks for various reasons. They are formed under very special geological conditions, which require the encounter of unusual main components, such as the chromophores, responsible for the beautiful colors; the existence of open spaces to form crystals with large enough size, relatively good transparency, and no obvious post-growth events (such as a fracture) [5,8-14]. With regards to jade, not all tremolite rocks will form nephrite. In addition to the diagenesis, the formation of nephrite also requires special jade forming processes to make the rock structure more dense and delicate, reaching the gem-quality [15].

China is a country with a large variety of gemstones. Traditionally, China has been regarded as the most important source for nephrite. China's jade culture has a history of more than 8000 years [16]. The Chinese jewelry industry has made great development, with the economic growth and people's growing demand for jewelry. According to the official survey, the total retail sales of China's jewelry industry was about $\$ 95$ billion in 2020, including $\$ 40$ billion of gems [17]. Meanwhile, over the past decades, continuous exploration works have newly discovered a large variety of gemstones resources in China [18-23] (Figure 1). The vast land with various geological and geochemical backgrounds is rich in gemstone resources with potential for new deposits discoveries. It follows that a new and systematic summary of the distribution characteristics of gem resources in China is necessary. This paper aims to comprehensively introduce the distribution of gemstone deposits and gemological and mineralogical characteristics of gemstone in China so as to provide further guidance for exploration.

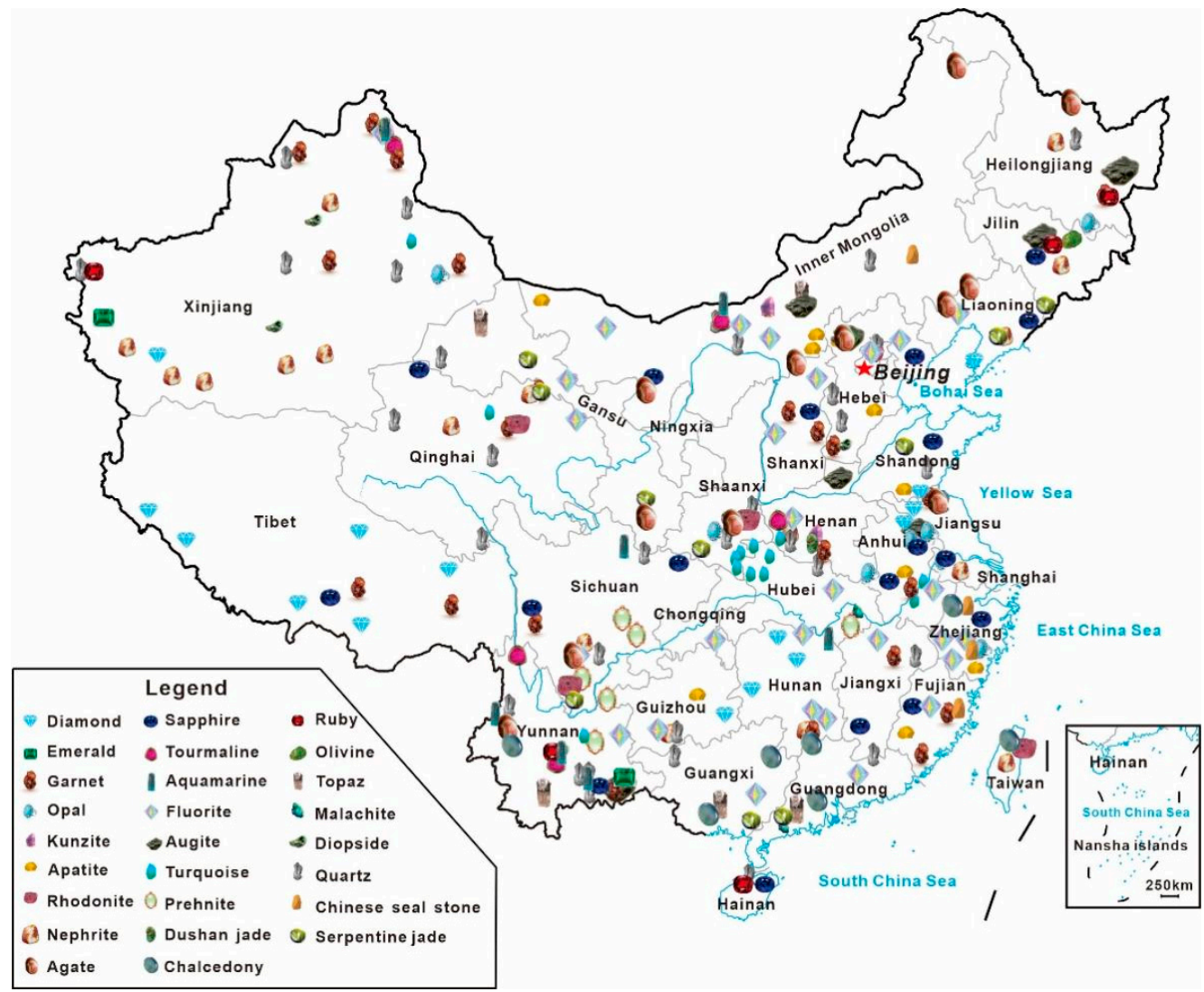

Figure 1. Distribution of gem deposits in China. The base map was revised from the Standard Map of China. 


\section{Distribution of Gemstone Deposits in China}

In China, a majority of metal and gemstone deposits are related to several orogenic belts and igneous/pegmatitic provinces [24-27], such as the giant Altai pegmatite province, the Yinshan orogenic belt, the Kunlun-Qilianshan orogenic belt, the Qinling orogenic belt, the Tibet-Sanjiang orogenic belt, and the eastern coastal region of China (Figure 2). Wherein more than two hundred gemstone deposits and/or occurrences have been discovered, with more than 60 different gemstone varieties. Gemstone representations in the different Chinese provinces have been summarized in Table 1. In general, gemstone deposits/occurrences were formed in different geological processes and can be divided as follows: (1) the igneous rocks-related deposits, (2) the pegmatite (and derived fluids) related deposits, (3) the regional metamorphism-related deposits, and (4) the chemical weathering and leaching-related deposits.

Igneous rocks are the common host rocks for many gemstone deposits, represented by diamond, sapphire, olivine, garnet, etc. In the eastern coastal region of China (Figure 1), extensive Cenozoic mafic/ultramafic magmatism resulted in the formation of numerous gemstone deposits [28]. Sapphire, spinel, olivine, garnet, and zircon with well-developed crystals are usually found in basalts [18,29]. More than 15 economic ore deposits are related to this Cenozoic magmatic event, represented by the Changle sapphire deposit in Shandong, the Penglai sapphire deposit in Hainan, the Jiaohe olivine deposit in Jilin, and the Zhangjiakou olivine deposit in Hebei. The giant Tan-Lu fault zone in the eastern North China Craton is the ascent pathway for basaltic magmas (Figure 2).

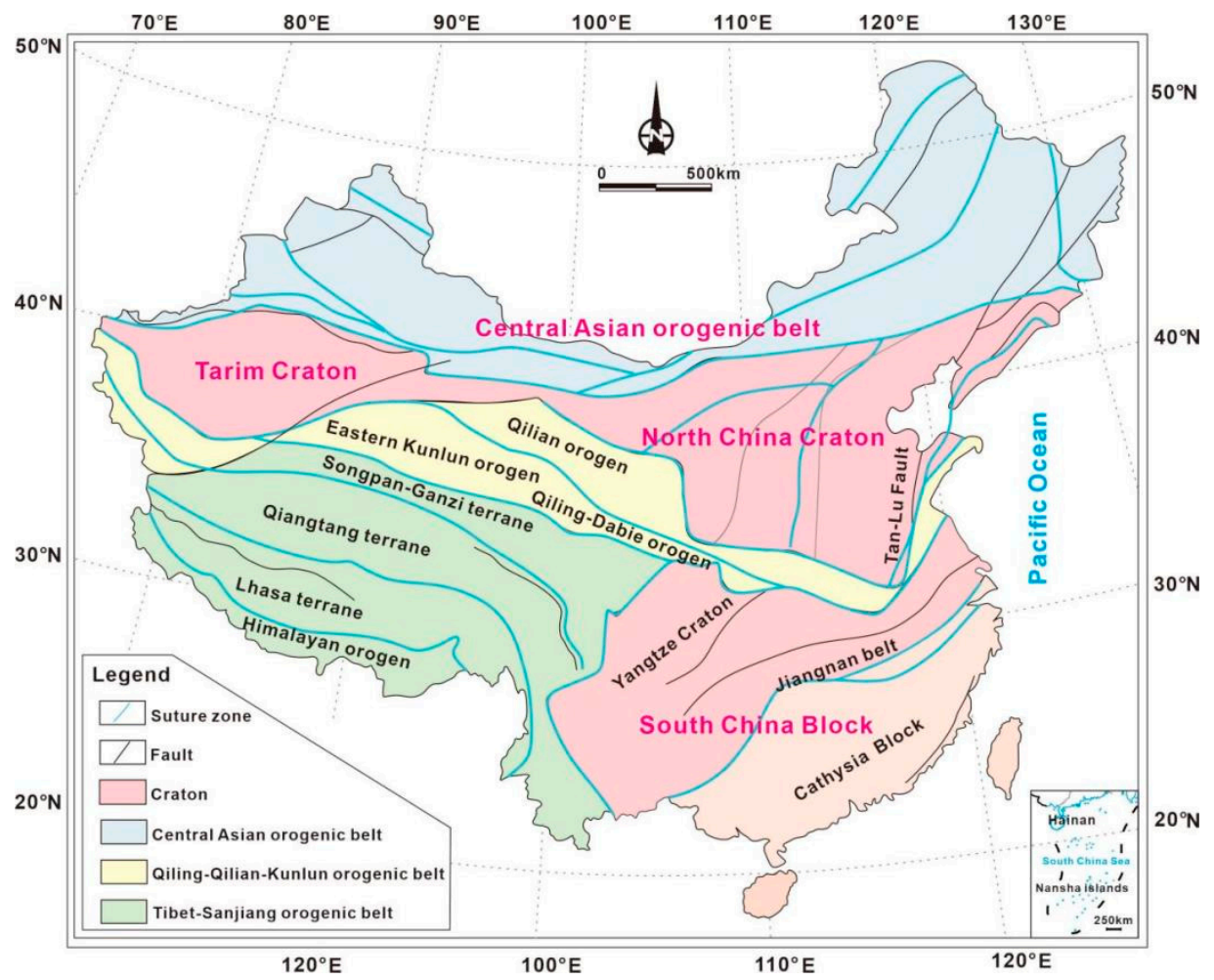

Figure 2. Generalized geological map and tectonic sub-division of China (modified after Qiu et al. [26]). 
Table 1. The distribution statistics of Chinese gemstones in each province.

\begin{tabular}{|c|c|c|}
\hline & Province & Gemstones \\
\hline \multirow{9}{*}{ Eastern China } & Beijing & Rhodonite; Malachite \\
\hline & Hebei & $\begin{array}{c}\text { Sapphire; Olivine; Garnet; Apatite; Pyroxene; } \\
\text { Diopside; Agate; Quartz; Prehnite }\end{array}$ \\
\hline & Jiangsu & Diamond; Quartz; Nephrite \\
\hline & Zhejiang & $\begin{array}{c}\text { Opal; Fluorite; Chalcedony; Quartz; Chinese Seal } \\
\text { stone }\end{array}$ \\
\hline & Fujian & Olivine; Chinese Seal stone \\
\hline & Shandong & $\begin{array}{c}\text { Diamond; Sapphire; Garnet; Serpentine jade; } \\
\text { Inkstone }\end{array}$ \\
\hline & $\begin{array}{l}\text { Guangdong } \\
\text { Hainan }\end{array}$ & $\begin{array}{l}\text { Topaz; Malachite; Chalcedony; Quartz; Inkstone } \\
\text { Olivine }\end{array}$ \\
\hline & Taiwan & Chalcedony; Quartz; Rhodonite; Nephrite \\
\hline & Shanxi & Olivine; Apatite \\
\hline \multirow{7}{*}{ Central China } & Anhui & $\begin{array}{c}\text { Diamond; Apatite; Malachite; Turquoise; } \\
\text { Inkstone }\end{array}$ \\
\hline & Jiangxi & Aquamarine; Malachite \\
\hline & Henan & $\begin{array}{l}\text { Tourmaline; Fluorite; Kunzite; Pyroxene; } \\
\text { Turquoise; Quartz; Nephrite; Dushan jade }\end{array}$ \\
\hline & Hubei & Malachite; Turquoise; Prehnite \\
\hline & Hunan & Diamond; Aquamarine; Nephrite \\
\hline & Inner Mongolia & Apatite; Pyroxene; Kunzite; Chinese Seal stone \\
\hline & Guangxi & $\begin{array}{c}\text { Topaz; Chalcedony; Quartz; Nephrite; } \\
\text { Serpentine jade }\end{array}$ \\
\hline \multirow{8}{*}{ Western China } & Sichuan & $\begin{array}{l}\text { Emerald; Aquamarine; Agate; Quartz; } \\
\text { Rhodonite; Prehnite; Nephrite }\end{array}$ \\
\hline & Guizhou & Diamond; Nephrite \\
\hline & Yunnan & $\begin{array}{l}\text { Ruby; Emerald; Tourmaline; Olivine; Garnet; } \\
\text { Aquamarine; Topaz; Malachite; Diopside; } \\
\text { Quartz; Prehnite; Chalcedony; Agate }\end{array}$ \\
\hline & Tibet & Diamond \\
\hline & Shananxi & Emerald; Turquoise; Rhodonite \\
\hline & Gansu & Topaz; Apatite; Agate; Serpentine jade; Inkstone \\
\hline & Qinghai & $\begin{array}{l}\text { Rhodonite; Nephrite; Serpentine jade } \\
\text { Diamond; Ruby; Emerald; Tourmaline; }\end{array}$ \\
\hline & Xinjiang & $\begin{array}{l}\text { Aquamarine; Apatite; Spodumene; Diopside; } \\
\text { Chalcedony; Nephrite }\end{array}$ \\
\hline \multirow{3}{*}{ Northeastern China } & Liaoning & $\begin{array}{c}\text { Diamond; Olivine; Quartz; Prehnite; Nephrite; } \\
\text { Serpentine jade }\end{array}$ \\
\hline & Jilin & Olivine; Nephrite; Sapphire \\
\hline & Heilongjiang & Opal; Nephrite \\
\hline
\end{tabular}

Although many pegmatite belts/provinces were found in China, only a few of them generated gemstones, mainly distributed in the Gaoli-gongshan-Ailaoshan region in Yunnan (tectonically in the Tibet-Sanjiang orogenic belt), the Altai region in Xinjiang and the Jiaoligetai region in Inner Mongolia (in the Central Asian orogenic belt), and the Lushi region in Henan (in the Qiling-Dabie orogenic belt) (Figure 2). Gemstone-producing pegmatites are highly differentiated, and gemstones tend to grow in pegmatitic cavities. Meanwhile, some gemstone crystals occur among rare metal deposits in pegmatites as the associated minerals. However, most of them show small-scale, constituting medium to small-sized deposits or occurrences. Most pegmatite-related deposits formed during the Yanshanian orogenic epoch and the Himalayan period, displaying a genetic relationship with tectonic-magmatic activities [30-32]. The largest one is the giant Altai pegmatite province located in the margin of Xinjiang province, among which the Koktokay No. 3 granitic pegmatite is famous for its huge gemstone reserves, such as tourmaline, aquamarine, spodumene, spessartine, moonstone, quartz, apatite, and topaz [33]. The formation of Dayakou emerald in Malipo, Yunnan is a representative case that involves magmatic- 
hydrothermal fluids. Generally, emeralds grow in pegmatites and quartz veins, especially in strongly altered locations [34].

Metamorphism is usually associated with deposits that produce gem-grade garnet, ruby, quartz, spinel and scapolite, such as the Yuanjiang ruby deposit in Yunnan and the Aktao ruby deposit in Xinjiang. Notably, regional metamorphism has generated the majority of jade deposits in China, like nephrite and serpentine jade. Turquoise from the Shaanxi and Hubei provinces shows a unique occurrence, which precipitated during chemical weathering and leaching.

Some placer deposits are occasionally found near primary deposits, such as the Yuanshui diamond placer deposit in Hunan, the Penglai sapphire placer deposit in Hainan, and the Donghai garnet placer deposit in Jiangsu.

\section{Gemstone Deposits in China}

According to the gemstone varieties, there is a separate summary for each type of gemstone, mainly including geographical location, geological background, mineralogical characteristics, genesis, history, etc. In addition, the representative chemical compositions of ruby, sapphire, tourmaline, olivine, garnet, serpentine jade, turquoise, aquamarine and nephrite jade from different deposits have been compiled in Supplementary Tables S1-S4 (see in Supplementary Materials).

\subsection{Diamond}

Diamond deposits are mainly located in the North China Craton (Figure 2), including the Mengyin deposit of Shandong province and the Wafangdian deposit of Liaoning province, as well as a few small-scale deposits/occurrences found in Hunan, Guizhou, Jiangsu, Anhui, Xinjiang and Tibet $[35,36]$. The Mengyin diamonds are composed of type-I and type-II diamonds. These crystals are mostly dodecahedron, octahedron (Figure 3a) or a combination, and a small proportion of them show cube, twins, and polycrystalline aggregates. These diamonds present colorless, yellow, brown, gray, green, and black with the particle size mostly ranging from 0.8 to $8 \mathrm{~mm}$ and the weight from 0.08 to $0.5 \mathrm{ct}$, but the largest one named "Changlin Diamond" up to $158.79 \mathrm{ct}$, which was mined from alluvial deposit. Common inclusions are graphite, olivine, garnet, sulfide minerals, and hematite $[37,38]$. However, the Wafangdian deposits can produce both gem-quality and industrial-use diamonds. The diamonds formed in the continental lithosphere at depths of 150 to $250 \mathrm{~km}$. They are transported to the surface by kimberlite eruptions [39-41]. The Wafangdian diamonds are predominantly type-I, and the inclusions are the same as the Mengyin diamonds $[35,40]$. They are colorless, yellow, gray, brown, light-blue, pink, and black. More than half of the diamonds are over $1 \mathrm{~mm}$ in size, and the largest one weighs 48 carats. The host rock of diamonds from Mengyin and Wafangdian is mainly kimberlites (Figure 3b) [41]. 

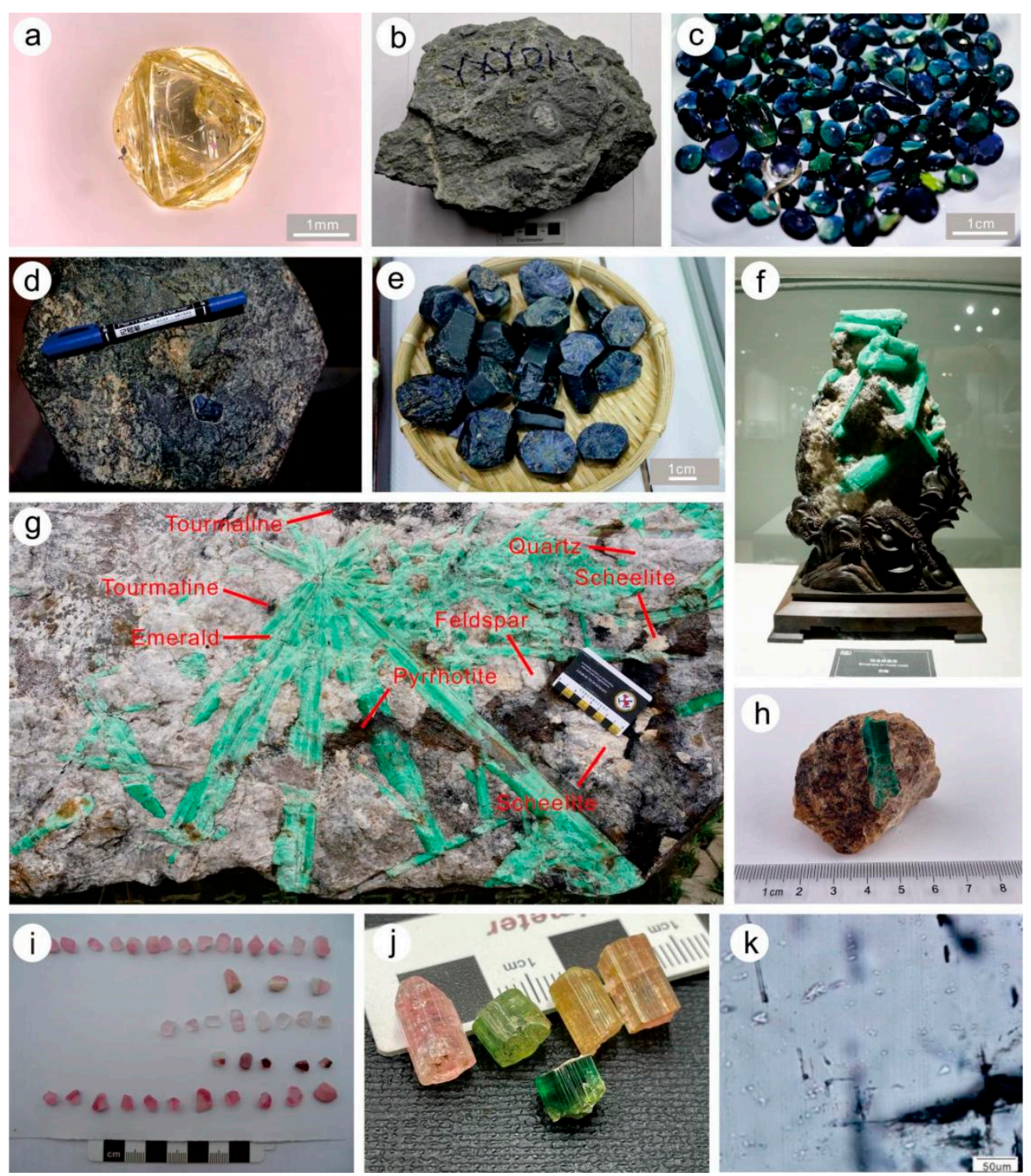

Figure 3. (a) The octahedral diamond mined in Changmazhuang in Mengyin, Shandong province. (b) The porphyritic kimberlite in Xiyu, Mengyin, Shandong province. (c) Sapphires from Changle, Shandong province. (d) Changle sapphire occurs in hexagonal columnar alkaline base. (e) The edges and corners of Changle sapphire crystal are mostly round and etched, and black capsules can be observed on the surface. (f) Dayakou emeralds from Yunnan intergrowth with quartz, calcite, scheelite. This sample measures 26 by 17 by $11 \mathrm{~cm}$. (g) Emeralds from Yunnan intergrowth with quartz, calcite, scheelite, feldspar, pyrrhotite and tourmaline. (h) The Davdar emerald from Xinjiang occurs in carbonaceous limestone. (i) Gem-grade pink tourmalines from Ailao Mountain, Yunnan. (j) The colorful tourmaline from Yunnan. (k) Needle-shaped fluid inclusion in tourmaline from Altay, Xinjiang. (Figure $3 \mathrm{a}$ is courtesy of Zhiyuan $\mathrm{Chu}$, and Figure $3 \mathrm{f}$ is collected in the Geological Museum of China).

\subsection{Sapphire}

Sapphire deposits in China were found in Cenozoic alkaline basalt from the late 1970s to the early 1980s. The largest basaltic sapphire deposit is located in Changle, Shandong province. The Changle sapphires usually occur as columnar or barrel-shaped crystals in olivine or alkaline olivine basalt (Figure 3d). Sapphire-bearing basalt contains a variety of mantle-derived xenoliths and megacryst minerals. The crystal edges of sapphires are mostly eroded, which present a subangular and rounded shape, and there is a layer of the black capsule on the crystal surface (Figure 3e). Sapphires from Changle are famous 
for their large grain size and well-developed crystals. However, these sapphires are dark blue and commonly are developed color zonation with alternating dark blue and yellow bands (Figure 3c). The color zonation is attributed to the variable Fe concentration in the crystal [29]. Besides, the Changle sapphire shows an incomplete hexagonal zonation along the C-axis, forming a special trapiche sapphire [42]. LA-ICP-MS analysis [43,44] shows that sapphire in basalt is rich in $\mathrm{Ti}, \mathrm{Fe}$, and $\mathrm{Ga}$ but poor in $\mathrm{Cr}$, whereas metamorphic sapphire is rich in $\mathrm{Cr}$, poor in $\mathrm{Fe}, \mathrm{Ti}$, and $\mathrm{Ga}$. The trace elements in the Changle sapphires contain $\mathrm{Mg}$, Al, Si, Ti, V, Cr, Fe, Ga. And the Ga concentration (>100 ppm) in Changle sapphire is consistent with that of most other basalt-type sapphires [43].

Besides, metamorphism-related sapphires are found in Fuping, Hebei province. The orebodies of the Fuping sapphire deposit are stratified and occur as the lenticles in migmatites, of which the protoliths are Archean sedimentary rocks. Orebodies are generally 100 to $800 \mathrm{~m}$ in size, about $1 \mathrm{~m}$ in thickness, and several tens to several hundred meters in depth. It is generally acknowledged that sapphire crystallized from the Al-rich melt during the migmatization process [45]. There are abundant inclusions, cracks, and partings in sapphire, leading to poor transparency. The primary inclusions are healing fractures, gas-liquid inclusions, and needle-like rutile [44]. Compared with metamorphism-related sapphires, the Fe and Ga concentration in Fuping sapphires is much higher, while the concentration of $\mathrm{Ti}$ is relatively lower. By comparing the contents of $\mathrm{Cu}$ and $\mathrm{Ga}$ in the Fuping sapphires are higher than sapphires from Madagascar, Burma, and Sri Lanka [43,44].

\subsection{Ruby}

More than ten ruby occurrences/deposits have been discovered in China. The Ailaoshan ruby deposit in Yunnan is mostly hosted by marbles or in secondary placer deposits. Ruby crystals, ranging in size up to $5 \mathrm{~cm}$ and of rose-red to dark purple color, have a similar color with the Vietnamese rubies in appearance [46,47]. The Ailaoshan ruby crystals present the shape of barrel, double-cone or plate. The ruby has more impurities, polymorphic twin and cracks [48], making it mostly translucent to opaque, which is appropriate to be cut as a cabochon.

The rubies in Baicheng, Xinjiang province, were also produced in the Ordovician marble [49]. The Baicheng ruby is the barrel, short columnar, irregular granular single crystal and granular aggregate. Most crystal fissures are developed, and the growth striation can be observed on the crystal surface. Ruby is light pink with a rose-red color, mostly transparent to translucent. The Baicheng rubies are characterized by significantly higher $\mathrm{Cr}$ and lower Fe [50]. The Baicheng ruby contains abundant mineral inclusions, such as calcite, pyrite, sphalerite, diaspore and a small amount of needle-columnar inclusions [50].

\subsection{Emerald}

Emerald deposits are rarely distributed in China, mainly in Yunnan, Shaanxi, Sichuan, and Xinjiang [34,51-54]. Emeralds from Dayakou, Yunnan province, were formed during multi-stages in the Early Cretaceous [55], divided into pegmatite and hydrothermal oreforming stages [34]. Most emeralds in Dayakou come from felsic pegmatite veins, and the common minerals in felsic pegmatite veins are quartz, feldspar, emerald, scheelite, tourmaline, pyrrhotite and so on (Figure 3g). The Dayakou emeralds are green, bluegreen, yellow-green, and color zonations common, showing a light green and white core and a green rim. The crystal clarity is poor, with numerous healing cracks and fractures penetrating the surface and clusters of fluid inclusions [55,56]. The crystal is usually hexagonal columnar or plate-shaped, with obvious longitudinal lines, irregular erosion marks, and hexagonal pits on the cylindrical surface, and the particle size is generally $0.5 \sim 5 \mathrm{~cm}$ (Figure 3f). The major composition of Dayakou emerald is characterized by a higher concentration of $\mathrm{V}$ than $\mathrm{Cr}$, defined as the $\mathrm{V}$-dominant emerald [56]. The $\mathrm{Al}^{3+}$ at the $\mathrm{Y}$ position of the octahedron in the lattice is unsaturated, mainly replaced by $\mathrm{Mg}^{2+}$, $\mathrm{V}^{3+}, \mathrm{Fe}^{2+}$; the channel of the beryl crystal is dominated by $\mathrm{Na}$. The content of Cs (average $1754 \mathrm{ppm})$ is the highest among emeralds in the world [56,57]. 
There are 12 emerald occurrences at Davdar in the Xinjiang province. However, most orebodies are small-scale, composed of emerald-bearing calcite veins and calcite quartz veins, ranging from 3 28 $\mathrm{m}$ in length and $0.2 \sim 1.6 \mathrm{~m}$ in thickness, hosted by carbonaceous limestone and shale (Figure 3h) [58,59]. The Davdar emeralds are light to dark green with high saturation and color zonations, showing a light core and a dark rim [60]. There are a lot of healing fissures and secondary fissures with iron impregnation in the Davdar emerald. Common mineral inclusions include calcite, feldspar, quartz, and black carbonaceous. Three-phase fluid inclusions containing a bubble and multiple (single) cubic salt are characteristics of the Davdar emeralds. The chromophore of Davdar emerald is characterized by higher $\mathrm{Cr}$ content than $\mathrm{V}$. The replacement degree of $\mathrm{Al}^{3+}$ in the crystal lattice is similar to that of Dayakou emerald, and the main replacement ions are $\mathrm{Mg}^{2+}, \mathrm{Cr}^{3+}$ and $\mathrm{Fe}^{2+}$. The alkali metal ions in the beryl channel are mainly $\mathrm{Na}^{+}$and $\mathrm{K}^{+}$[52]. Studies on fluid inclusions and oxygen isotopes indicate that the formation temperature and pressure (P/T conditions) of Davdar emeralds are 325 to $375^{\circ} \mathrm{C}$ and 10 to $160 \mathrm{MPa}$, respectively [8].

Besides, several new emerald occurrences have been discovered recently, such as the Zhenan tungsten-beryllium deposit (in Shaanxi province) and the Jiajika lithium deposit (in Sichuan province) [53,54]. The Zhenan emeralds display relatively high $\mathrm{V}_{2} \mathrm{O}_{3}$ contents, different from the Cr-dominant emeralds [54]. It is assumed that the formation of the emerald should be related to magmatic activities within the area, similar to the Dayakou emerald deposit in genesis [54].

\subsection{Tourmaline}

The tourmaline deposits in China are mainly distributed in the Altay of Xinjiang, Ailaoshan of Yunnan, Lushi of Henan (Figure 3i-k). These are mostly related to the felsic magmatic activity, formed in the Yanshan-Himalayan period or the Silurian period. Tourmalines usually occur as associated minerals in some granitic pegmatite rare metal deposits, forming medium-small scale tourmaline occurrences. Eluvial placer tourmaline deposits are mainly formed by weathering and accumulation of tourmaline-bearing pegmatites. Tourmaline has physical properties of wear resistance and corrosion resistance [61,62], enable it to resist weathering effectively and remain in place. Tourmalines are colorful, including red, pink, green, and a small number of blue-green tourmalines (Figure 3j). In addition, color zonations are developed in tourmalines from the Altay area. Green tourmaline is one of the most important varieties in Altay. The tourmaline crystals are transparent to translucent, well-shaped, usually of thin columnar, and occur as crystal clusters. Tourmaline usually contains abundant slender irregular filiform gas-liquid inclusions, hair-like gas-liquid inclusions, and healing fissures parallel to the crystal C-axis (Figure 3k). In addition, irregular linear, tubular thrust inclusions and flat membrane-like gas-liquid inclusions parallel to the C-axis are often observed in tourmalines [63].

\subsection{Olivine}

Gem-grade olivine deposits are widely distributed in many provinces, such as Hebei, Jilin, Shanxi, Liaoning, Fujian, Hainan, and Yunnan. The Damaping deposit in Hebei and the Dunhua deposit in Jilin are the main olivine producing areas in China, among which Damaping deposit is the largest one. The olivines are usually generated in lherzolite xenoliths and peridotite xenoliths (Figure 4b). The Damaping olivine deposit was formed in the late Miocene (24.5-13.6 Ma) [64]. Olivines are granular, with a size between 4 and $7 \mathrm{~mm}$, and the largest one has a side length of $34 \times 20 \times 15 \mathrm{~mm}$. The Damaping olivines are mostly bright yellow-green with high transparency and vitreous luster (Figure 4a). They have the typical 'water lily leaf' inclusions. The Dunhua deposit in Jilin is the second-largest olivine-producing mining area in China. The olivine is found in the mantle-derived peridotite xenolith in the Tertiary basalt [65], and other associated minerals include enstatite, diopside, and spinel [66,67]. The olivine color is mostly yellowish-green, with a size of 5-8 mm. They also have 'water lily leaf' inclusions typically. In addition, Kuandian of Liaoning, Tianzhen of Shanxi, Mingxi of Fujian, Wenchang of Hainan, and 
Maguan of Yunnan also produce olivine. However, the yield scale is relatively low, and the quality is not as good as the olivines found in Damaping and Dunhua.
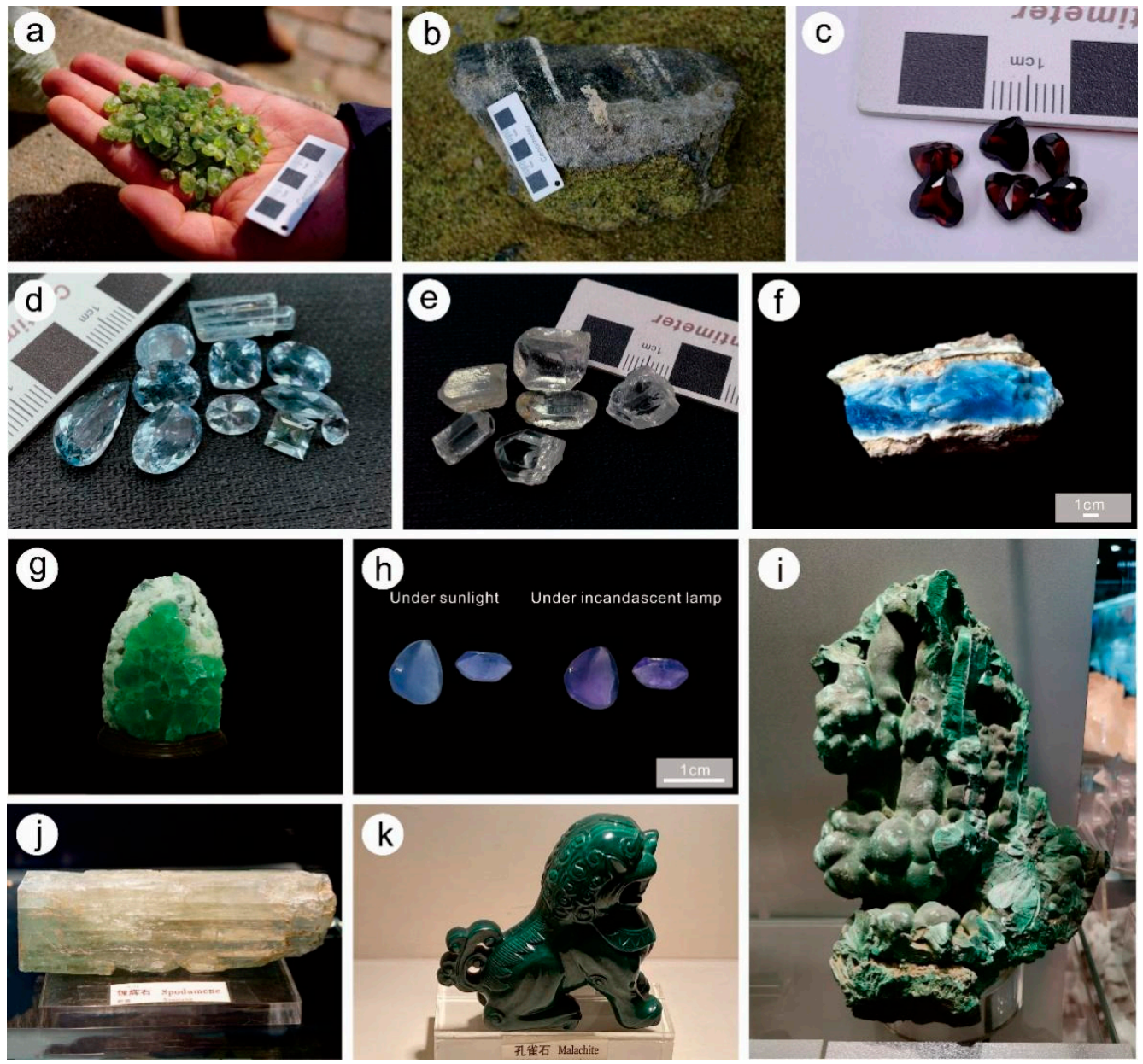

Figure 4. (a) The high-quality olivines from Damaping, Hebei province. (b) The peridotite xenoliths in basalt, ca. $12 \mathrm{~cm}$. (c) The red pyropes from Maguan, Yunnan province, have high color saturation and good transparency. (d) The high-quality aquamarine from Xinjiang province. (e) The topaz from Yunnan province with good crystal shape and high transparency. (f) The blue opal from Lishui, Zhejiang province. (g) The Fluorites from Fujian province intergrowth with calcite. (h) The colorchanging fluorite from Hebei province. (i) The Guangdong malachite has villous crystals and occurs as botryoidal aggregate. (j) Spodumenes from Xinjiang can develop into giant crystals with perfect crystal shapes. (k) The high-quality malachite carving from Guangdong province with typically peacock green and banded color zonation. (Figure $4 \mathrm{~g}-\mathrm{k}$ are collected in the Geological Museum of China).

\subsection{Garnet}

Garnet deposits are widely distributed in many provinces. For instance, the red pyropes in Maguan, Yunnan province, are found in peridotite xenolith within maficultramafic volcanic rocks, especially basaltic volcanic breccia pipes. Most pyropes in Maguan are famous for their high color saturation and good transparency (Figure 4c). The size of crystal fragments is generally $0.2-2.5 \mathrm{~cm}$, and a small amount of them can reach more than $0.3-0.4 \mathrm{~cm}$. Generally, inclusions are rarely observed under the microscope. The pyropes were formed by the crystallization of mantle-derived magma [68,69]. Skarnrelated garnet deposit is represented by the Nanminghe Fe deposit in Hebei. The associated minerals are diopside, magnetite, calcite, pyrite, and quartz. The garnets are light brown to brown. They are found as granular aggregates, and most of them are idiomorphic or 
hypidiomorphic. They also have solid or gas-liquid inclusions with poor transparency [70]. Garnet in Jinan, Shandong province, has various colors, and some of them have color zonations, which are found in skarn and pegmatite. Garnets in skarn are mainly brown-red or brown-yellow, with few green ones. The size is generally $1-5 \mathrm{~cm}$, and the largest one can be more than $10 \mathrm{~cm}$. The inclusions are mainly gas-liquid two-phase inclusions. Whereas, garnets in pegmatite are mainly green or yellow. The size is usually small, generally $0.2-0.6 \mathrm{~cm}$. They usually contain needle-like actinolite and feldspar inclusions [71].

\subsection{Aquamarine}

Aquamarine resources are abundant in China, mainly distributed in Altai of Xinjiang province, Inner Mongolia province, Pingjiang and Mufushan of Hunan province, Sichuan province, and Yunnan province. These deposits are hosted in granitic pegmatites and hydrothermal veins [72]. In Altay, Xinjiang, aquamarine is mainly produced in the early pegmatitic stage and the late hydrothermal stage of microcline pegmatite [73]. The color of aquamarine in this region is lighter and is generally light blue or blue-green (Figure 4d). The aquamarine deposits in Jiangxi are mainly quartz vein type, and the mineralization assemblages are generally relatively simple, mainly aquamarine-mica quartz or potash feldspar [74]. Aquamarine has mostly well-developed crystals and is produced as a single crystal. There are a lot of irregular unhealed cracks and 'rain filaments' shape, punctate and hexagonal column inclusions in the crystal [75]. The good-quality aquamarine from Ailaoshan in the Yunnan province is often produced in the core of the pegmatite cavity [76]. The aquamarine grains produced in the Galigongshan region in western Yunnan are large and of good quality, but the orebodies are generally small in scale, ranging from a few to tens of meters in length and 0.5 to $5 \mathrm{~m}$ in width. The aquamarine produced in Pingwu of the Sichuan province is famous for its unique flat plate-shaped crystal, accompanied by gem-quality orange transparent scheelite and bright black cassiterite crystal. The chemical composition of aquamarine in this area is characterized by rich alkali and poor iron, and the crystals are rich in gas and liquid inclusions, and fluid inclusions containing carbonate daughter crystals have been discovered [77].

\subsection{Topaz}

Two types of topaz deposits have been discovered in China. One is pegmatite-type, distributed in Taishan of Guangdong province, Panjiajing of Gansu province, southern Ailaoshan and Gaoligong Mountain-Fugong of Yunnan province. The other is quartz vein type, mainly found in the wolframite deposits in Guangxi province. The topaz crystals are light yellow, colorless, blue, light reddish-brown, and orange, with high transparency. Most inclusions are gas-liquid two-phase inclusions, and a group of well-developed cleavage can be found within the large and complete topaz crystal. Taishan topaz is the main source of colorless and radiation-modified blue topaz in China. The igneous rocks in the mining area are acidic medium coarse-grained biotite granite of the Yanshan period. The albitization and dolomitization metasomatism are obvious in pegmatites. The pegmatites are mainly composed of feldspar, quartz, and mica. Whereas gem-quality topaz crystallized in some pegmatitic cavities. Topaz in Panjiajing, the Gansu province, is colorless to light yellow and anamorphic columnar crystal with a diameter of $0.2 \sim 3 \mathrm{~cm}$ and a length of $1 \sim 7 \mathrm{~cm}$. The crystal is transparent and flawless and grows vertically in the cavity wall [78]. Topaz in Yunnan occurs in the granitic pegmatite, related to the tectonic-magmatic event in the Yanshanian. Topaz from the Ailaoshan and Gaoligongshan-Fugong of the Yunnan province is mainly colorless, has good crystal shape and high transparency (Figure 4e), and contains few inclusions.

\subsection{Apatite}

Apatite is distributed in many provinces in China, such as Anhui, Shanxi, Inner Mongolia, Hebei, Gansu, and Xinjiang. The Anhui apatite color is mostly light yellow with high transparency but usually presents a bad crystal shape. The apatite in Lingqiu, Shanxi 
province, is gray-green with good transparency. They have well-shaped and smooth crystal surfaces. However, black inclusions can be observed inside apatites, and the crystal is usually broken, affecting its commercial value. The granitic pegmatite in Xinjiang can produce rose-red apatite with a size between 0.3 and $2 \mathrm{~cm}$ or colorless transparent apatite with a size of about $1 \mathrm{~cm}$ [79]. Apatite is also found in granitic pegmatite dikes in Inner Mongolia [80]. Apatite formed in the pegmatite stage is associated with minerals such as pyroxene, biotite, and feldspar.

\subsection{Opal}

Opal is found within Henan, Shaanxi, Yunnan, Anhui, Jiangsu, Heilongiiang, Zhejiang provinces. Blue opals are found in Lishui, Zhejiang province (Figure $4 \mathrm{f}$ ). Most cannot reach the gem-grade with poor color saturation [81]. These blue opals are considered of volcanic origin [82]. In contrast, opal in Heilongiiang is generally crusty or amygdaloidal aggregate. The colors are light brown, turpentine, brownish-green, and dark green. The Heilongjiang opals may be an epithermal deposit. Generally, the formation of opals is related to $\mathrm{SiO}_{2}$-bearing water filling into the fracture of rocks or the circulation of $\mathrm{SiO}_{2}-$ bearing hot spring water.

\subsection{Fluorite}

Fluorites are found in Zhejiang, Hebei, and Henan. The host rocks of the Wuyi fluorite deposit are mainly the Yanshanian volcanic rocks. The ore-forming elements come from Ca-rich volcanic or subvolcanic rocks and surrounding F-rich biotite plagioclase gneiss. Fluorite in China is mostly green, purple, yellow, and colorless, and some of them show color zonation. The color of the fluorites is usually concentrated at the margin and corner of the crystal. Most fluorites are mostly cubic and transparent to translucent, with 3 to $5 \mathrm{~cm}$ (Figure $4 \mathrm{~g}$ ). Interestingly, fluorite appears to change color under different light sources. However, the color-changing effect of fluorite in different producing areas is distinct: the fluorite from Zhejiang displays grayish-blue in sunlight and reddish-purple under incandescent lamps, while the fluorite from Fuping, Hebei province displays blue in sunlight and blue-purple under incandescent lamps (Figure 4h). The fluorites in Wuyi, Zhejiang province, are genetically related to hydrothermal fluids. In addition, the parental magma for the Songxian fluorite deposits in Henan is the Yanshanian granitoids [83-85].

\subsection{Malachite}

Malachite resources are mainly found within Hubei, Guangdong, Jiangxi, Anhui, and Yunnan provinces. Malachites often occur in primary copper deposits or the upper oxidation zone of intermediate-mafic rocks, such as basalts, dacites, and diorites. Thus, Malachite is usually associated with some copper-bearing minerals, such as azurite. The Daye malachite deposits occur in contact oxidation zones between quartz diorite and the Permian to Triassic carbonate rocks. The Yangchun malachite deposit is a typical chemicalleaching sedimentary deposit, which is formed by the interaction between copper-rich fluid and marble. The Yanqing malachite is found in the oxidation zone of metamorphic $\mathrm{Cu}-\mathrm{Fe}$ deposit [86].

The malachite in Daye, Hubei province, and Yangchun, Guangdong province, usually has high quality. Malachite is typically peacock green with a banded or concentric color zonation. The orebody in the Daye deposit occurs as reniform, botryoidal, crusty, or concentric aggregates. The appearance is composed of bands and rings with different shades of green to light green color. The structure is concentrically layered or radial fibrous. It has two characteristics: the mineral particles from the center to the outside become more and more coarse, and the concentric bands become wider. Due to the long mining history, the yield of the Daye malachite is relatively small at present.

Malachite from Yangchun, Guangdong province, has villous crystals. The orebody occurs as botryoidal, stalactitic, crusty, radiating, or vein aggregates (Figure 4i). The formation of Yangchun Malachite is associated with the fluid/water leaching process. 
In the early stages, the malachites are dark green, emerald green and have relatively high hardness. Therefore, it is often used as a carving material (Figure 4k). Whereas, in the late leaching stage, the malachites are pink-green and fragile, with fibrous and radiating structures. Compared with malachites in other regions, the Yangchun malachite has a relatively higher density. In Yanqing, Beijing, malachite is usually green, but some malachites contain blue or yellow impurities [86].

\subsection{Pyroxene}

Gem-quality diopside is found in Xinjiang, Yunnan, Hebei provinces. Diopside deposit from Xinjiang is mainly produced in granulite and marble as stratified and lenticular veins. Most diopsides from Xinjiang and southern Yunnan are yellow-green, close to olivine, with obvious color zonation. The diopside in skarn or diorite from Handan, Hebei province, is green with low luminosity. With vivid green and high transparency, chrome-diopsides from Zhangjiakou, Hebei province are crystallized within spinel peridotite.

Spodumenes are related to pegmatites in genesis [87], and in addition to spodumene, the commonly paragenetic minerals in pegmatite include quartz, albite, muscovite, and tourmaline. The Xinjiang and Inner Mongolia spodumenes are famous for their high quality. The color of spodumene in Xinjiang is variable, such as colorless, rosy, light yellow-green, and vivid green (Figure $4 \mathrm{j}$ ). And some spodumenes can develop into giant crystals up to $5 \times 10 \times 25 \mathrm{~cm}$ [88]. The spodumene from Guanpo, Henan province, is white, light green, and gray, and its luster is weaker than that of other mining areas. In Inner Mongolia, a variety of purple spodumenes, such as rose, violet, light purple, deep purple, and a small amount of colorless transparent spodumene, were found during the mining of tourmaline and aquamarine.

\subsection{Turquoise}

Turquoise has been used as traditional jewelry by Chinese people for a long time. Gem-grade turquoise is widespread in China, such as the Ankang and Luonan deposits in Shaanxi province, the Xichuan deposit in Henan province, and the Maanshan deposit in Anhui province. The turquoise deposits in Shaanxi, Hubei, and Henan constitute the largest weathering-type turquoise metallogenic belt in China, almost located in the southeast Qinling Orogenic Belt [89]. Most turquoises are associated with Cu deposit, and two possible genesis models of turquoise thus have been proposed, namely, the hydrothermal metasomatism and chemical weathering and leaching of copper mineral, respectively [90].

The turquoise from Shiyan, Hubei province has been a significant turquoise-producing region worldwide due to its excellent quality and considerable resource prospect. The orebodies are mainly hosted in the Lower Cambrian black silicalite and carbon-siliceous slate, and the distribution is controlled by regional fault structure [89,91]. These ore veins/veinlets are lenticular, bead, or lentil shape, ranging from 1-5 $\mathrm{m}$ in length and $0.2-0.5 \mathrm{~m}$ in width. Turquoises are blue, sky blue, yellow-green, and precipitate as noduleshaped aggregates (Figure 5a). The large aggregation formed a size of 30-40 cm [91]. The estimated reserve of turquoise in Shiyan is ca. 2000 tonnes [92]. The Maanshan turquoise is mostly accompanied by copper and iron orebodies in the Maanshan iron deposit and co-crystallized minerals are quartz, kaolinite, and limonite [93]. The surrounding rock of turquoise veins generally underwent alteration and formed kaolinites [90]. Turquoise usually occurs as botryoidal and kidney shapes with blue-green or sky blue colors. In Ankang, turquoise is mostly developed in the regional fault zone and the inside interlayer. The host rocks of turquoise are mainly siliceous slate and carbonaceous phyllite. The orebody is elongated, ranging from $80-100 \mathrm{~m}$ in length and 1-6 $\mathrm{m}$ in width. Turquoises are mainly nests-like, clumps, and schistic. Nests-like and clumpy turquoises, ranging from sky blue to light blue, show better hardness and less quantity than schistic turquoises, which generally are light blue to yellow-green and off-white (Figure 5b). 

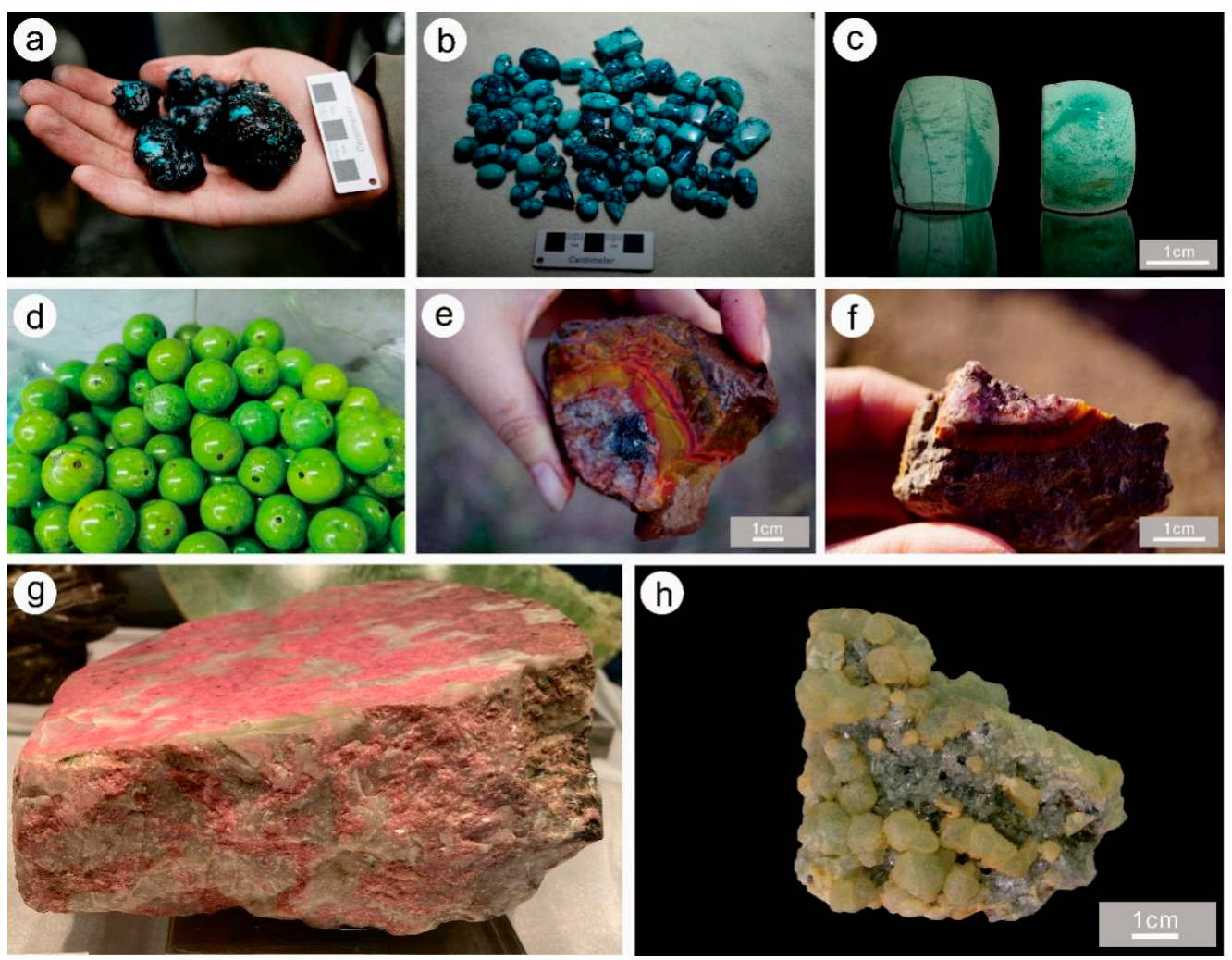

Figure 5. (a) The turquoise ore stones from Dongzigou mining in Zhushan, Hubei province. (b) The turquoise from Ankang County in Shaanxi province. (c) The Zhushan turquoise with "raindrops" pattern, Hubei. (d) The new variety of turquoises from Hubei province show yellow-green color with high saturation, and these beads are about $3 \mathrm{~cm}$ in diameter. (e) The Warring States Red Agate with red, yellow, and brown zonations, Hebei province. (f) The rocks containing amethyst and agate from Hebei province. (g) The pink-bright red rhodonites occur in white quartz as a homogeneous bulk. (h) The high-quality prehnite from Yunnan with yellow-green. (Figure $5 \mathrm{~g}$ is collected in the Geological Museum of China).

Content and occupation of some trace elements, e.g., $\mathrm{Cu}, \mathrm{Fe}, \mathrm{V}, \mathrm{Ni}$ in the lattice, would cause the variable color of turquoise. Some turquoises have special patterns, called "raindrop" turquoise (Figure 5c). The formation of the raindrop pattern is controlled by $\mathrm{Cu}, \mathrm{Fe}, \mathrm{V}$, and $\mathrm{Ni}$. The blue raindrops have higher $\mathrm{Cu}$ content, while brown raindrops have higher $\mathrm{Fe}, \mathrm{V}$, and $\mathrm{Ni}$ content [94]. In addition, turquoise from China has some unique patterns, for example, (1) a water ripple pattern on the turquoise surface, (2) a spiderweb pattern, (3) blue ulan flower, (4) water grass lines, (5) a unique three-color turquoise, similar to glazed pottery in the Chinese Tang Dynasty (thus called "Tang tricolor turquoise") $[95,96]$. The unique pattern of spiderweb, ulan flower and water grass lines are composed of limonite or carbon, different from other turquoises in the world. Recently, the market has a new popular variety of turquoises, called rapeseed yellow turquoise, which shows yellow-green color with high saturation (Figure 5d). Impurity minerals of uranyl vanadate cause the color, and the high contents of $U$ and $V$ have been detected in the yellow-green area $[94,97]$.

\subsection{Quartz}

Quartz is rich in most provinces in China. The formation of gem-quality quartz is usually associated with pegmatites and derived hydrothermal fluids. The quartz yield in Jiangsu province is the highest, accounting for more than half of the yield in China. Quartz in Donghai, Jiangsu Province, is colorless, milky white, purple, yellow, or smoky. The largest reserves are colorless crystals, which generally form larger crystals with fluid 
inclusions and mineral inclusions. The mineral inclusions are mainly chlorite, epidote, specularite, rutile, anthophyllite, tremolite, and black tourmaline. The Angao deposit in Henan province is an important amethyst deposit, mainly producing hexagonal shortcolumnar amethyst crystals with excellent transparency and few inclusions. In contrast, amethyst from the Yunnan province is small crystals and presents uneven tones with dot-like, cloud-like fluid inclusions [98].

Chalcedony is mainly found in Xinjiang, Yunnan, Guangdong, Guangxi, Zhejiang, Taiwan provinces. Taiwan blue chalcedony is uniformly blue, blue-green, which is a color related to trace $\mathrm{Cu}$. It was precipitated from Si-rich hydrothermal fluids and filled in the hole of mafic igneous rocks, volcanic tuffs, and volcanic breccias [99]. Chalcedony from Longling, Yunnan province is mainly in yellow and red, which is very popular with local people. According to ultraviolet-visible spectrophotometry, it presents the typical trivalent iron spectrum, so this yellow color is mainly caused by elemental Fe [100].

Agate is mainly found in Shaanxi, Gansu, Inner Mongolia, Hebei, Heilongjiang, Liaoning, Yunnan, Shanxi, Jiangsu provinces. Agate has variable color, including white, red, green, and blue. Red agate from Yunnan, Sichuan, and Gansu provinces is colored by hematite inclusions, called Nanhong Agate in China. Onyxes with red and yellow bonds occur in Hebei and Liaoning provinces and are called the Warring States Red Agate in China because the bands resemble jade patterns from the Warring States Period. The Xuanhua deposit in Hebei province produces the famous Warring States Red Agate, showing interphase distributed red, yellow, and brown zonations (Figure 5e). The mineral association of Warring States Red Agate is mainly chalcedony and quartz, together with minor calcite, cryptocrystalline iron, calcium, and clay mineral (Figure 5f) [101].

\subsection{Rhodonite}

Rhodonite often occurs in some Mn ore deposits in Beijing, Qinghai, Shaanxi, Sichuan, Taiwan. Rhodonite from Changping, Beijing, is rose-red, pink, or fuchsia, and its shape presents a thick plate. Rhodonite shows two different occurrences, of which the pink rhodonite is embedded in white quartz-like petals and a homogeneous bulk collectively composed of pink-bright red rhodonites (Figure 5g). The formation of the Changping rhodonite deposit is related to hydrothermal metasomatism of the Cambrian Mn-rich tuffs [102]. Another main producing-region is the Shangzhou rhodonite deposit, where the orebody is mainly composed of more than $95 \%$ rhodonite and a small number of spessartine, calcium-rhodonite, rhodochrosite, quartz, manganese-calcite, and dolomite [103].

\subsection{Prehnite}

The main producing areas of prehnite include the Yunnan province and Sichuan province. In addition, some small occurrences are found in Hebei and Liaoning provinces. Prehnite primarily occurs in the cavity of basalts. It is the precipitation product of hydrothermal fluids derived from magmatic differentiation. Prehnite from China is mostly yellow, green, colorless and white, among which the strong green is high-grade, followed by the bright blue-green and yellow-green prehnite (Figure $5 \mathrm{~h}$ ). Black hornblende and brown epidote are common inclusions in prehnite. The prehnite in Daye Fe deposit, Hubei province, occurs in skarn's cavity or structural fracture and coexists with chabazite, stellite, and calcite.

\subsection{Nephrite}

Nephrite jade, a rock that is also termed as tremolite jade or Hetian jade, mainly consists of the massive microcrystalline to cryptocrystalline fibrous amphibole, both tremolite $\left[\mathrm{Ca}_{2} \mathrm{Mg}_{5} \mathrm{Si}_{8} \mathrm{O}_{22}(\mathrm{OH})_{2}\right]$ and actinolite $\left[\mathrm{Ca}_{2}\left(\mathrm{Mg}, \mathrm{Fe}^{2+}\right)_{5} \mathrm{Si}_{8} \mathrm{O}_{22}(\mathrm{OH})_{2}\right]$ mineral. Its good color, luster, texture, and toughness has been highly favored by Chinese collectors, which has extremely important values for ornamental carvings and jade culture (Figure 6) $[22,23,104,105]$. In China, the evolution of jade carving craftsmanship and the value of jade cultural connotation show the development tendency of diversification. And 
the nephrite jade carving is one of the oldest and most valuable art forms, representing the processes of jade materials and the effects of art presentation, respectively [106]. Therefore, the perfect combination of materials itself and craftsmanship makes nephrite jade invaluable (Figure 6).
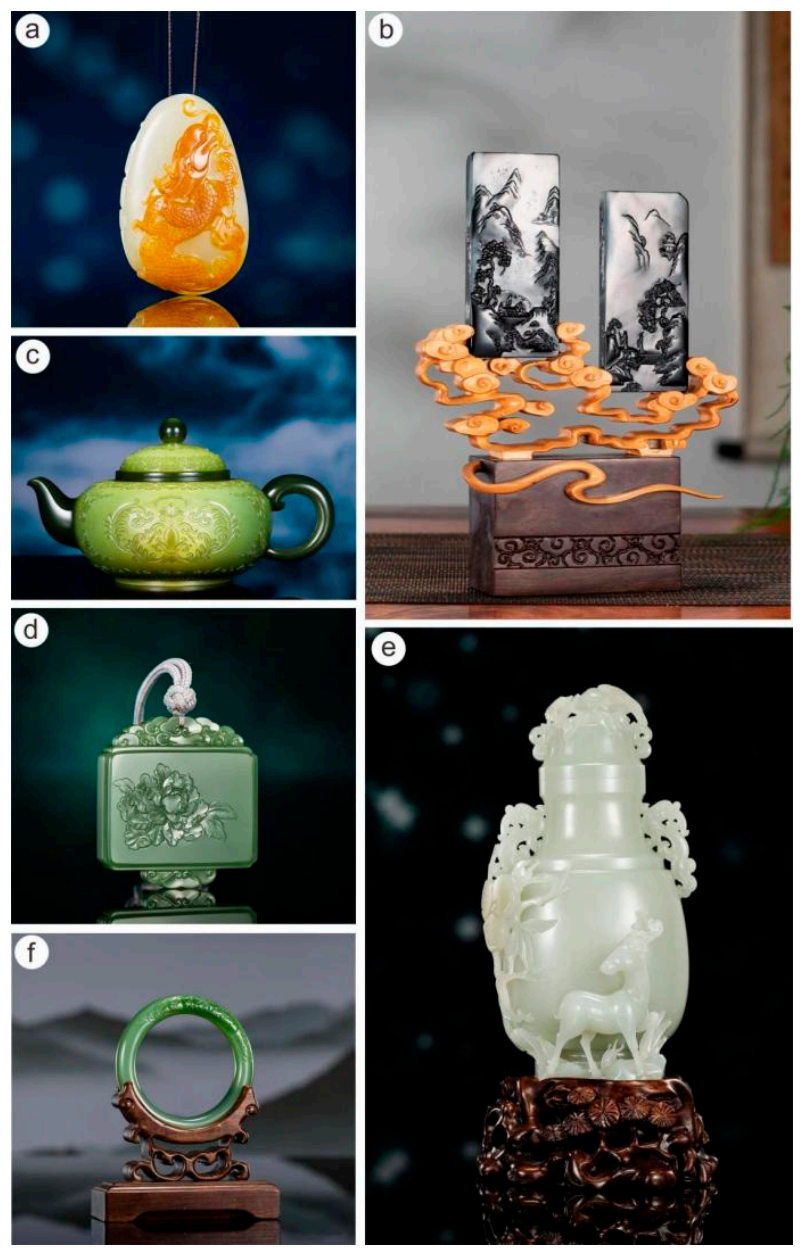

Figure 6. Representative nephrite jade carving photographs. (a) The white nephrite jade "Dragon" carving by Yongfang Wang from Hetian placer deposits, Xinjiang Province. (b) The black nephrite jade carving by Junhua Gao from Hetian placer deposits, Xinjiang Province. (c) The light green nephrite jade "teapot" carving by Yufeng Zhu. (d) The green nephrite jade carving by Yong Sun. (e) The white nephrite jade carving with extremely complex crafts by Yijin Gao. (f) The green nephrite jade bracelet by Chunbo Chen. (Photographs are provided by Beijing Boguan International Auctioneering Co., Ltd., Beijing, China).

Most production of nephrite jade around the world came from the $1300 \mathrm{~km}$ long Hetian nephrite belt in the Western Kunlun Mountains in northwest China, which contains both high-quality primary and placer or secondary deposits [22,23,105,107]. With the continuous exploration of jade deposits, many novel nephrite jade deposits have emerged in Jilin, Heilongjiang, Henan, Guangxi, and Hunan province, China. Whereas, the mining scales of these deposits are relatively small, and the quality of jade is medium to general lever (e.g., [15,108-110]. Liu and Yu [15] summarized the nephrite jade deposits in China's major producing regions into two categories: magmatic hydrothermal type and metamorphic hydrothermal type, which currently present relatively systematic classification standards. The former deposits are mainly distributed in Shache-Yecheng, Hotan-Yutian, Qiemo-Ruoqiang, Manasi, Xinjiang province, and Sanchakou and Golmud, Qinghai, Liyang, Jiangsu province, Luodian, Guizhou province, and Shimian, Sichuan province. The latter deposits are pre- 
dominately distributed in Xiuyan, Liaoning province, Luanchuan, Henan province, and Fengtien, Taiwan province. Recently, the youngest nephrite jade $(227.9 \pm 5.3 \mathrm{Ma})$ in the Chinese mainland has been discovered in the Yushigou ophiolite suite, NW China, revealing the formation of high-quality green nephrite (tremolite) within the convergent margin [23].

Generally, the formation mechanism of nephrite jade is of great significance in mineralogical, petrological and tectonic settings. It has been linked to either contact metasomatism of dolomitic marble with granitic intrusions, or between silicic rocks that interacted with serpentinized mantle peridotite, constituting the dolomite-related type (D-type) and serpentine-related type (S-type), respectively [15,23,104,111-115]. Compared with D-type nephrite jade, the origin of S-type nephrite jade is relatively complicated, becoming an important topic of frontier research. Nephrite jade deposits exist in large reserves and abundant natural occurrence characteristics in China, mainly related to carbonatite and serpentinite bodies. The enrichment of jade ore bodies is usually involved with hydrothermal processes. These two types of nephrite jade usually show white and green appearance, respectively, attributed to distinct contents of trace elements such as $\mathrm{Fe}^{2+}, \mathrm{Cr}^{3+}$ occupied in the predominated mineral.

\subsection{Serpentine Jade}

In ancient China, serpentine jade from Qilian was generally used to make up wine cups. Serpentine jade deposits are widespread in China, mostly in Liaoning, Shandong, Qinghai, Gansu, Guangxi provinces (Figure 7a-c). According to the type of surrounding rocks, serpentine jade deposits can be divided into carbonate rocks-related and ultramafic rocks-related deposits, both of which are attributed to serpentinization. The serpentine jade from Xiuyan, Liaoning province, is regarded as superior in quality. The orebodies occur as lenses with different sizes and irregular shapes, ranging from $50-100 \mathrm{~m}$ in length and 1-5 $\mathrm{m}$ thickness [116]. The colors of Xiuyan serpentine jade are mainly green, yellowgreen, and dark green. It shows unevenly distributed silk floss or opaque white cloudshaped inclusions (Figure 7c) [117]. The serpentine jade from Xiuyan is associated with the hydrothermal metasomatism of dolomite marbles (Figure $7 \mathrm{~b}$ ). In addition, the serpentine jade in Qilian, Qinghai province is dark green, and the color is uneven [117]. The Qilian serpentine jade contains a large amount of chromite and high content of $\mathrm{Cr}$ and $\mathrm{Ni}$, formed by metamorphism of ultramafic rocks [118].

\subsection{Dushan Jade}

The Dushan jade produced in Dushan, Henan province. Its orebody occurs in the gabbro. It is a kind of zoisite-anorthosite, composed of plagioclase and zoisite (Figure 7d,e). The color depends on mineral components, and the common colors are white, green-bluish green, purple, yellow, black, and pink (Figure 7e). The deposit genesis of Dushan jade is complex, mainly due to the magmatic-hydrothermal metasomatism.

\subsection{Inkstone}

The inkstone is one of the treasures of Chinese traditional culture. Its primitive function is to grind ink and pigment to a fine degree to facilitate writing. With the prosperity of social economy and culture, the shape of the inkstone gradually becomes exquisite. Its function has also developed from writing tools to artwork. Generally, sedimentary rock, metamorphic rock, and igneous rock all can be used as inkstone; thus, the common components are silicate and carbonate minerals. The inkstone has a variety of colors and patterns. "Duan inkstone" is purple and light green; "She inkstone" is mostly lividity; "Tao inkstone" is common green; and "Hongsi inkstone" is red and yellow with the filiform pattern (Figure 7f). Most of the inkstone deposits are related to marine sedimentation, and some are related to metamorphism after sedimentary diagenesis. The metamorphism would generate some interesting patterns and colors. 

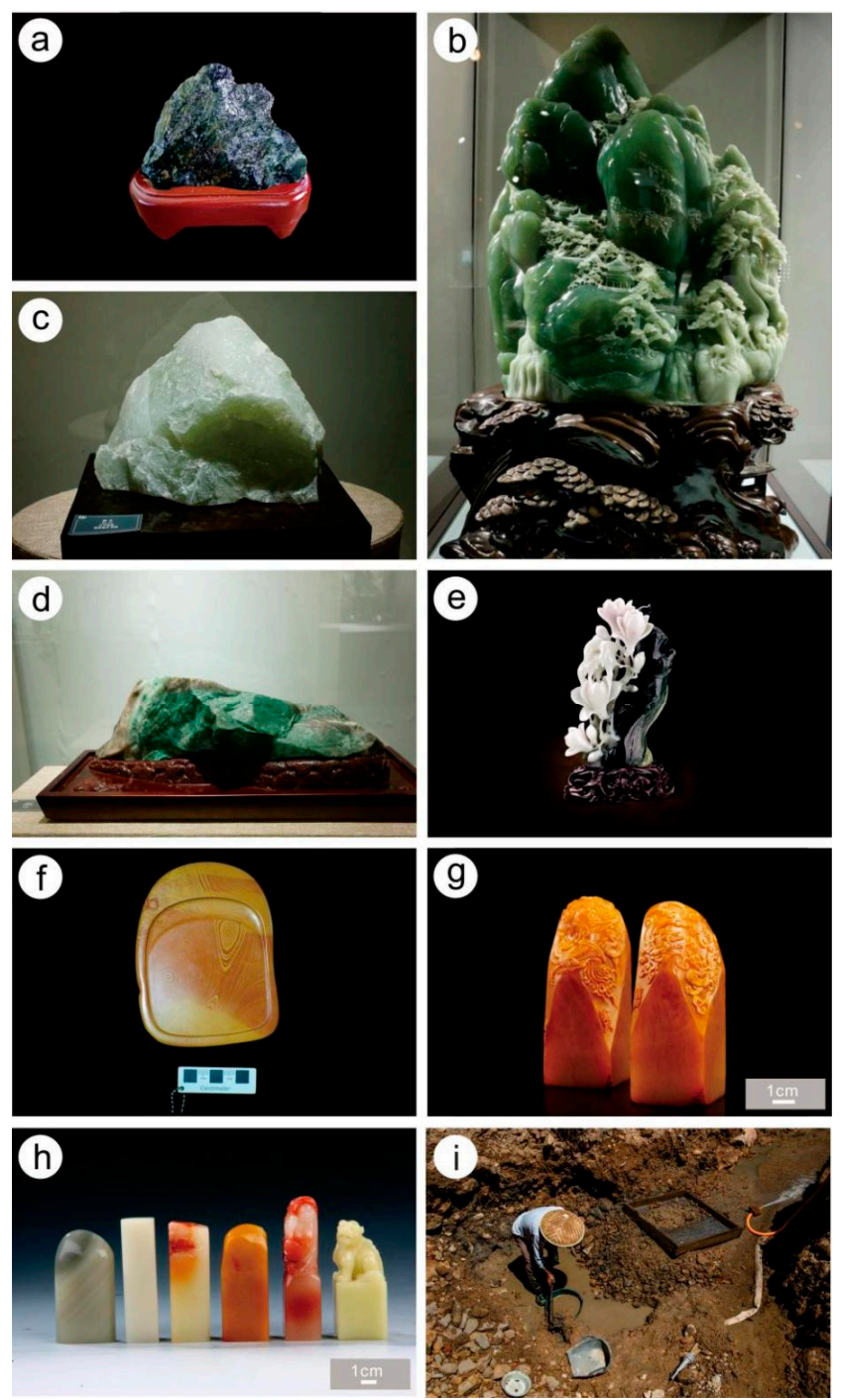

Figure 7. Representative jade carving photographs and mineral processing scene. (a) The serpentine jade carving from Shandong province. (b) The serpentine jade carving from Liaoning province. (c) The Xiuyan serpentine jade has unevenly distributed silk floss and opaque white cloud-shaped inclusions. (d) Dushan jade from Henan province. (e) The Dushan jade carving measures $19 \mathrm{~cm}$ high. (f) The Hongsi inkstone with the filiform pattern. (g) Seal stone used by ancient royalty was engraved with dragon and phoenix patterns. (h) Different colors of the Chinese seal stone. (i) Tianhuang stone (a kind of Chinese seal stone) processing scene. (Figure $7 \mathrm{~b}-\mathrm{d}$ are collected in the Geological Museum of China, and Figure 7e is provided by Beijing Boguan International Auctioneering Co., Ltd. (Beijing, China), and Figure $7 \mathrm{~g}$ is available from www.christies.com (accessed on 9 May 2016), and Figure $7 \mathrm{~h}$ is courtesy of Chunmao Yao).

\subsection{Chinese Seal Stone}

As early as hundreds of years ago, ancient Chinese people used stone to make seals (Figure 7g) [119]. The Chinese seal stone is a kind of artwork with historical and cultural characteristics of China. There are many varieties of seal stone in China. The producing areas are extremely extensive, among which the famous producing areas are Shoushan of Fujian, Qingtian of Zhejiang, Changhua of Zhejiang, Balin of Inner Mongolia (Figure $7 \mathrm{~g}-\mathrm{i}$ ). The seal stone is predominately composed of clay minerals with low hardness and exquisite material used for carving seals and artworks (Figure 7h). Magma events control the distribution of the Chinese seal stone deposits. The ore-bearing rock is dominated 
by Mesozoic intermediate-acid continental volcanic rock, among which tuff is the most favorable for mineralization [120].

\section{Conclusions}

This paper is an overview of the distribution of gemstone deposits in China, as well as related gemological and mineralogical characteristics. The vast land with various geological and geochemical backgrounds is rich in gemstone resources, also having the potential for new deposits discoveries. Gemstones in pegmatites, mostly distributed in Xinjiang, Yunnan and Inner Mongolia provinces, are related to granitic magma events and mainly occur in pegmatitic cavities and intensely altered positions. The representative gemstones from pegmatites are aquamarine, chrysoberyl, beryl, tourmaline, topaz, crystal, and apatite. The east and southeast of China are tectonically located at the suture line between the Eurasian Continental Plate and the Pacific Plate, in which the frequent tectonic and magmatic activities in this region formed large-scale basaltic and kimberlite magmas. Consequently, basalt-related gemstones (e.g., sapphire, spinel, olivine, garnet, zircon) and kimberlite-hosted diamonds are the most important gems produced in this area. China is rich in nephrite resources; most economic nephrite deposits stretch for thousands of miles from Kashi Kurgan in the west to Ruoqiang in the east with considerable prospects. The formation of nephrite deposit is related to the carbonatite and serpentinite rocks involved in the metamorphic-metasomatic processes. Additionally, gem-quality turquoise and malachite prevailingly occur within the supergene oxidation zones of some copper and iron deposits in Hubei and Anhui provinces. Our present investigation aims to provide insights into the gemstone potential of China for further exploitation.

Supplementary Materials: The following are available online at https:/ / www.mdpi.com/article/10 .3390 / cryst11101189/s1, Table S1: Statistics of chemical compositions of emeralds in China (wt.\%), Table S2: Representative EPMA of various gem-quality minerals from China, Table S3: Representative Electron microprobe analysis (EPMA) of different nephrite jade from Xinjiang province, China, Table S4: Representative Electron microprobe analysis (EPMA) of different nephrite jade from other locations, China.

Author Contributions: Conceptualization, X.-Y.Y. and Z.-Y.L.; methodology, X.-Y.Y., Z.-Y.L., Y.Z. and L.-J.Q.; data curation, L.-J.Q.; writing—original draft preparation, X.-Y.Y., Z.-Y.L., Y.Z., L.-J.Q., C.Z., Z.-R.X., Y.-R.W., Y.Y., M.-K.W. and J.-X.W.; writing-review and editing, X.-Y.Y., Z.-Y.L., Y.Z., C.Z. and L.-J.Q.; supervision, X.-Y.Y.; funding acquisition, X.-Y.Y. All authors have read and agreed to the published version of the manuscript.

Funding: This study was financially supported by the project from the China Geological Survey (DD20190379-88).

Acknowledgments: We appreciate Fei Liu, Na-Li Sha, Jian-Jun Li, He-Jun Li, Jun-Ping Chen, ZhiYuan Chu, Han-Dong Zhang, Mao-Yong Li, Guo Chen and the Turquoise Culture Research Association, Zhushan, Hubei, China, for their assistance during field survey. We owe thanks to Yan Ao, Jun-Chao Shi, Yong-Feng Wang, Yu Zhang, and Lin-Su Lv for providing samples and photographs of gemstone.

Conflicts of Interest: The authors declare that they have no known competing financial interest or personal relationships that could have appeared to influence the work reported in this paper.

\section{References}

1. Fritsch, E.; Rondeau, B. Gemology: The Developing Science of Gems. Elements 2009, 5, 147-152. [CrossRef]

2. Yu, X.Y. Colored Gemmology; Geology Press: Beijing, China, 2016; pp. 15-26.

3. Groat, L.A. Gemstones. Am. Sci. 2012, 100, 128-137. [CrossRef]

4. Stern, R.J.; Tsujimori, T.; Harlow, G.; Groat, L.A. Plate tectonic gemstones. Geology 2013, 41, 723-726. [CrossRef]

5. Groat, L.A.; Laurs, B.M. Gem Formation, Production, and Exploration: Why Gem Deposits Are Rare and What is Being Done to Find Them. Elements 2009, 5, 153-158. [CrossRef]

6. Smith, E.M.; Shirey, S.B.; Richardson, S.H.; Nestola, F.; Bullocks, E.S.; Wang, J.H.; Wang, W.Y. Blue boron-bearing diamonds from Earth's lower mantle. Nature 2018, 560, 84-87. [CrossRef] 
7. Smith, E.M.; Ni, P.; Shirey, S.B.; Richardson, S.H.; Wang, W.; Shahar, A. Heavy iron in large gem diamonds traces deep subduction of serpentinized ocean floor. Sci. Adv. 2021, 7. [CrossRef] [PubMed]

8. Giuliani, G.; Groat, L.A.; Marshall, D.; Fallick, A.E.; Branquet, Y. Emerald Deposits: A Review and Enhanced Classification. Minerals 2019, 9, 105. [CrossRef]

9. Laurs, B.M.; Simmons, W.B.; Falster, A.U.; Anckar, B. Genesis of yellow manganese-rich elbaite from the Canary mining area, Lundazi, Zambia. Appl. Geochem. 2009, 24, 1113-1124. [CrossRef]

10. Groat, L.A.; Giuliani, G.; Stone-Sundberg, J.; Sun, Z.; Renfro, N.D.; Palke, A.C. A Review of Analytical Methods Used in Geographic Origin Determination of Gemstones. Gems Gemol. 2019, 55. [CrossRef]

11. Pezzotta, F.; Laurs, B.M. Tourmaline: The Kaleidoscopic Gemstone. Elements 2011, 7, 333-338. [CrossRef]

12. Hu, Z.; Zheng, Y.; Yu, P.; Wu, Y.; Wang, C. Gem-Grade Garnet with Metamorphic Origin in the Tiemurt Orogenic-Type Deposit, Chinese Altay Orogen: Texture, Chemistry, and Physicochemical Condition. Front. Earth Science. 2021, 9. [CrossRef]

13. Graham, I.; Sutherland, L.; Zaw, K.; Nechaev, V.; Khanchuk, A. Advances in our understanding of the gem corundum deposits of the West Pacific continental margins intraplate basaltic fields. Ore Geol. Rev. 2008, 34, 200-215. [CrossRef]

14. Franz, G.; Vyshnevskyi, O.; Taran, M.; Khomenko, V.; Wiedenbeck, M.; Schiperski, F.; Nissen, J. A new emerald occurrence from Kruta Balka, Western Peri-Azovian region, Ukraine: Implications for understanding the crystal chemistry of emerald. Am. Mineral. 2020, 105, 162-181. [CrossRef]

15. Liu, F.; Yu, X. Classification and mineralogical characteristics of nephrite deposits in China. Miner. Resour. Geol. 2009, 23, 375-380. (In Chinese with English Abstract)

16. Cai, K.; Chen, B.; Cui, Y.; Yuan, X. A preliminary study on the scientific understanding of jade in ancient China. Beijing, China, 2002; Geological History Research Institute of Geological Society of China: Beijing, China, 2002; Volume 5, pp. 1-5. (In Chinese)

17. Sha, N.; Liu, Y.; Fu, Y.; Zhang, X.; Wang, Y.F. 2020 China Jewelry Industry Development Report. China Gems Jades. 2021, 4, 47-57. (In Chinese)

18. Yu, X.; Wu, G.; He, X. Color forming mechanism and improvement of sapphire in Shandong. Depos. Geology. 1996, 15, 153-157. (In Chinese)

19. Liu, Y.; Zhang, B.; Yu, X.Y. Study on crystallographic characteristics and development prospect of beryl in Pingwu, Sichuan. Geol. Explor. 2001, 2, 55-57. (In Chinese with English Abstract)

20. Yu, X.; Zheng, Y.; Zhang, T.; Guo, H.; Long, Z.; Wan, J.; Zhang, C. The genesis of color zoning of emerald from Dayakou, Yunnan Province: Implication for multi-stage mining. Earth Sci. Front. 2020, 27, 116-125. (In Chinese with English Abstract)

21. Jiang, X.; Yu, X.; Guo, B.; Xu, P. A study of mineral inclusions in emeralds from Malipo, Yunnan Province, China. Acta Petrol. Mineral. 2019, 38, 279-286. (In Chinese with English Abstract)

22. Zhang, C.; Yu, X.; Jiang, T. Mineral association and graphite inclusions in nephrite jade from Liaoning, northeast China: Implications for metamorphic conditions and ore genesis. Geosci. Front. 2019, 10, 425-437. [CrossRef]

23. Zhang, C.; Yu, X.; Yang, F.; Santosh, M.; Huo, D. Petrology and geochronology of the Yushigou nephrite jade from the North Qilian Orogen, NW China: Implications for subduction-related processes. Lithos 2020, 380-381. [CrossRef]

24. Goldfarb, R.J.; Mao, J.-W.; Qiu, K.-F.; Goryachev, N. The great Yanshanian metallogenic event of eastern Asia: Consequences from one hundred million years of plate margin geodynamics. Gondwana Res. 2021. [CrossRef]

25. Wu, M.; Samson, I.; Zhang, D. Concentration of REE-Nb-Zr-Be in the Baerzhe Deposit, NE China: Insights from Textural and Chemical Features of Amphibole and Rare Metal Minerals. Econ. Geol. 2020, 116, 651-679. [CrossRef]

26. Qiu, K.; Goldfarb, R.J.; Deng, J.; Yu, H.; Gou, Z.; Ding, Z.; Wang, Z.; Li, D. Gold deposits of the Jiaodong Peninsula, eastern China. SEG Spec. Publ. 2020, 23, 753-773. [CrossRef]

27. Deng, Y.H. Gemstone (jade) deposit (I). J. Guilin Inst. Technol. 1991, 1, 113-120. (In Chinese)

28. Zhu, R.-X.; Yang, J.-H.; Wu, F.-Y. Timing of destruction of the North China Craton. Lithos 2012, 149, 51-60. [CrossRef]

29. Yu, X.; Niu, X.; Zhao, L. Characterization and Origin of Zonal Sapphire from Shandong Province, China. JOM 2015, 67, 391-397. [CrossRef]

30. Wang, T.; Tong, Y.; Jahn, B.-M.; Zou, T.-R.; Wang, Y.-B.; Hong, D.-W.; Han, B.-F. SHRIMP U-Pb Zircon geochronology of the Altai No. 3 Pegmatite, NW China, and its implications for the origin and tectonic setting of the pegmatite. Ore Geol. Rev. 2007, 32, 325-336. [CrossRef]

31. Zhou, Q.; Qin, K.; Tang, D.; Tian, Y.; Cao, M.; Wang, C. Formation Age and Evolution Time Span of the Koktokay No. 3 Pegmatite, Altai, NW China: Evidence from U-Pb Zircon and40Ar-39Ar Muscovite Ages. Resour. Geol. 2015, 65, 210-231. [CrossRef]

32. Wang, Y.; Zhou, Y.; Cai, Y.; Liu, H.; Zhang, Y.; Fan, W. Geochronological and geochemical constraints on the petrogenesis of the Ailaoshan granitic and migmatite rocks and its implications on Neoproterozoic subduction along the SW Yangtze Block. Precambrian Res. 2016, 283, 106-124. [CrossRef]

33. Zhu, Y.-F.; Zeng, Y.; Gu, L. Geochemistry of the rare metal-bearing pegmatite No. 3 vein and related granites in the Keketuohai region, Altay Mountains, northwest China. J. Asian Earth Sci. 2006, 27, 61-77. [CrossRef]

34. Long, Z.-Y.; Yu, X.-Y.; Jiang, X.; Guo, B.-J.; Ma, C.-Y.; You, Y.; Zheng, Y.-Y. Fluid boiling and fluid-rock interaction as primary triggers for emerald deposition: Insights from the Dayakou emerald deposit (China). Ore Geol. Rev. 2021, 139, 104454. [CrossRef]

35. Peng, Y.; Yu, L.; Zhou, Z. Distribution and utilization of diamond resources in China. Gems Gemmol. 2013, 15, 1-7. (In Chinese with English Abstract) 
36. Liu, F.; Yang, J.; Lian, D.; Yu, X.; Gwandu, R. Metallogenic features of diamondiferous kimberlites in Botswana and China: Enlightenment for exploration of the same type deposits. Geol. China 2019, 46, 43-76. (In Chinese with English Abstract)

37. Luo, S.X.; Ren, X.R.; Zhu, Y.; Chen, J.C.; Guo, Y.P.; Wei, T.L. Diamond Geology of Shandong; Shandong Science and Technology Press: Qingdao, China, 1999; pp. 106-127. (In Chinese with English Abstract)

38. Lv, Q.; Liu, F.; Chu, Z.Y.; Ge, Y.J.; Liu, X.; Jiao, Y.X. The mineralogical characteristics and comparison of diamonds in the three Kimberlite belts in Mengyin, Shandong Province. Acta Geol. Sin. 2021, 95, 1-14. (In Chinese with English Abstract)

39. Haggerty, S.E. Diamond genesis in a multiply-constrained model. Nature 1986, 320, 34-38. [CrossRef]

40. Zhang, B.L.; Chen, H.; Qiu, Z.L.; Lu, T.J.; Qin, S.C.; Ke, J.; Bi, L.J.; Zhang, J.; Sun, Y.; Chen, B.H.; et al. Diamond Origin Study under the Framework of the United Nation Kimberley Process; Geological Press: Beijing, China, 2013; (In Chinese with English Abstract).

41. Ni, P.; Zhu, R. Evaluating the diamond potential of kimberlite-hosted diamond deposits from the North China Craton. Acta Geol. Sin. 2020, 94, 2557-2573. (In Chinese with English Abstract)

42. Shen, C.; Liu, Y. Gemmological and Mineralogical Characteristics of Trapiche Sapphire from Changle, Shandong Province. Gems Gemol. 2016, 18, 21-23. (In Chinese)

43. Niu, X. LA-ICP-MS Analysis and Zoning of Changle Sapphire in Shandong Province. Master Thesis, China University of Geosciences, Beijing, China, 2014. (In Chinese with English Abstract)

44. Wang, H. LA-ICP-MS Analysis and Mechanism of Alexandrite Effect of Sapphire from Fuping. Master's Thesis, China University of Geosciences, Beijing, China, 2009. (In Chinese with English Abstract)

45. Song, S. Analysis on the Production Characteristics and Genesis of Plain Corundum from Fuping, Hebei Province. Master's Thesis, China University of Geosciences, Beijing, China, 2015. (In Chinese with English Abstract)

46. Liu, X. Study on Gemological Characteristics and Improvement Technology of Yunnan Rubies. Ph.D. Thesis, East China University of Science and Technology, Shanghai, China, 2011. (In Chinese with English Abstract)

47. Wang, W.; Scarratt, K.; Emmett, J.L.; Breeding, C.M.; Douthit, T.R. The Effects of Heat Treatment on Zircon Inclusions in Madagascar Sapphires. Gems Gemol. 2006, 42, 134-150. (In Chinese with English Abstract) [CrossRef]

48. He, M.; Zhu, X.; Hong, B. Raman spectral characteristics of inclusions in rubies from Yuanjiang, Yunnan. Gems Gemol. 2001, 04, 25-27. (In Chinese with English Abstract)

49. Wang, S. A Book of Gem-Jade Resources in China; Science and Technology Academic Press: Beijing, China, 1999; (In Chinese with English Abstract).

50. Liu, X.; Yang, N.; Yue, Y.; Deng, S.; Chen, X. Gemological characteristics of rubies from Baicheng, Xinjiang. Gems Gemol. 2018, 20, 1-8. (In Chinese with English Abstract)

51. Long, Z.; Yu, X.; Zheng, Y. Ore formation of the Dayakou emerald deposit (Southwest China) constrained by chemical and boron isotopic composition of tourmaline. Ore Geol. Rev. 2021, 135, 104-208. [CrossRef]

52. Marshall, D.; Pardieu, V.; Loughrey, L.; Jones, P.; Xue, G. Conditions for emerald formation at Davdar, China: Fluid inclusion, trace element and stable isotope studies. Miner. Mag. 2012, 76, 213-226. [CrossRef]

53. Dai, H.; Wang, D.; Liu, L.; Yu, Y.; Dai, J. Mineralogical characteristics of emeralds in the Jieka rare metal deposit, Sichuan, China. Acta Petrol. Miner. 2018, 38, 135-141. (In Chinese with English Abstract)

54. Dai, H.; Wang, D.; Liu, L.; Huang, F.; Wang, C. Study of emerald-grade beryl from tungsten-beryllium polymetallic deposit in Zhen'an, Shaanxi Province by electron probe and micro-area X-ray diffraction. Rock Ore Testing. 2018, 37, 336-345. (In Chinese with English Abstract)

55. Xue, G.; Marshall, D.; Zhang, S.; Ullrich, T.D.; Bishop, T.; Groat, L.A.; Thorkelson, D.J.; Giuliani, G.; Fallick, A. Conditions for Early Cretaceous Emerald Formation at Dyakou, China: Fluid Inclusion, Ar-Ar, and Stable Isotope Studies. Econ. Geol. 2010, 105, 339-349. [CrossRef]

56. Zheng, Y. Characteristics of Channel Water Spectrum and Origin Traceability of Dayakou Emerald in Yunnan. Master's Thesis, China University of Geosciences, Beijing, China, 2020. (In Chinese with English Abstract)

57. Hu, Y.; Lu, R. Unique Vanadium-Rich Emerald from Malipo, China. Gems Gemol. 2019, 55, 338-352. [CrossRef]

58. Yu, X.; Li, J.; Wang, L.; Shi, Y.; Luo, W. Geological background of emerald (beryl) mineralization region in Tashkurgan, Xinjiang. Acta Geosci. Sin. 2011, 32, 419-426. (In Chinese with English Abstract)

59. Jing, C. Study on Mineralogical and Spectral Characteristics of Emeralds in Davdar Region, Xinjiang. Master's Thesis, University of Geosciences, Beijing, China, 2015. (In Chinese with English Abstract)

60. Wang, L.; Peng, X.; Li, J.; Ren, W.; Shi, Y. Geological characteristics and prospecting mineralogy of emerald (beryl) ore in Xinjiang. Acta Mineral. Sin. 2011, 31, 604-609. (In Chinese with English Abstract)

61. Van Hinsberg, V.J.; Henry, D.J.; Dutrow, B.L. Tourmaline as a Petrologic Forensic Mineral: A Unique Recorder of Its Geologic Past. Elements 2011, 7, 327-332. [CrossRef]

62. Henry, D.J.; Novák, M.; Hawthorne, F.; Ertl, A.; Dutrow, B.L.; Uher, P.; Pezzotta, F. Nomenclature of the tourmaline-supergroup minerals. Am. Miner. 2011, 96, 895-913. [CrossRef]

63. Deng, J. Study on Gemstone Characteristics of Tourmaline in Altai Region of Xinjiang. Master's Thesis, Hebei Geosciences University, Shijiazhuang, China, 2016. (In Chinese with English Abstract)

64. Yu, J. Mineralogical Researching of Olivine in Hebei Damaping. Master's Thesis, China University of Geosciences, Beijing, China, 2009. (In Chinese with English Abstract) 
65. Zhang, L.; Wen, J.; Li, X. Development and Utilization of Gems Resources in Jilin Province. Chang. Inst. Tech. Nat. Sci. Edi. 2002, 4, 11-13. (In Chinese)

66. Chen, C. Study on the Mineralogical Characteristic of Olivine in Jilin Dunhua. Master's Thesis, China University of Geosciences, Beijing, China, 2020. (In Chinese with English Abstract) [CrossRef]

67. Xu, G.; Zhou, P. Geological characteristics and gemstone grade classifi cation method of Songnanshan olivine gem deposit in Dunhua Yiqi, Jilin Province. Jilin Geology. 2019, 38, 64-67. (In Chinese with English Abstract)

68. Li, J.; Bo, G.; Zhao, J. Analysis on the mineralization characteristics and genesis of gem-grade magnesia garnet from Bazhai to Muchang area, Maguan County, Yunnan. Priv. Technol. 2014, 08, 89-92. (In Chinese)

69. Bo, G.; Zhao, J. Mineralization and Division of Mineralization Areas of Gemstones in Wenshan Area, Yunnan. Yunnan Geology 2015, 3, 352-358. (In Chinese)

70. Ruan, C. The Gem-Mineralogy Characteristics of Garnet in the Nanminghe Skarn Iron Deposit in Wuan, Hebei. Master's Thesis, China University of Geosciences, Beijing, China, 2020. (In Chinese with English Abstract) [CrossRef]

71. Chen, Y.; Yu, X.; Yang, Y.; Ruan, C. A study of gemological and mineralogical characteristics and color zonation of garnets from Jinan, Shandong Province. Acta Petrol. Mineral 2021, 40, 581-592. (In Chinese with English Abstract)

72. Ruan, Q.; Zhang, L.; Zhang, C.; Lei, W.; Rao, C.; Liao, B.; Zeng, W. Study on the genesis and characteristics of beryl. Miner. Resour. Geol. 2008, 3, 265-269. (In Chinese with English Abstract)

73. Qu, M. Mineralogical and Gemological Study of Aquamarine from Keketuohai in Aletai of Xinjiang. Master's Thesis, China University of Geosciences, Beijing, China, 2014. (In Chinese with English Abstract)

74. Zhou, W.Q. Characteristics of Beryl Deposits and Prospecting Direction of Beryl Gems in Jiangxi Province. Geol. Jiangxi. 1994, 1, 26-35. (In Chinese)

75. Gao, H.; Tao, L. Spectroscopic study on aquamarine from Altay region, Xinjiang. Xinjiang Youse Jinshu. 2018, 41, 112-114 (In Chinese)

76. Li, Z.; Li, W.; Ji, J.; Ji, J.; Wang, Y.; Shi, G. Study on the genesis and rock-forming simulation experiments of aquamarine-bearing pegmatites of Ailaoshan, Yunnan, China. Acta Petol Sin. 2007, 23, 39-52. (In Chinese with English Abstract)

77. Liu, Y.; He, M.; Zhang, D.; Yu, X.; Pan, Z. Study on gemological characteristics of beryl from Pingwu, Sichuan. Gems Gemmol. 2001, 3, 31-34. (In Chinese with English Abstract)

78. Zou, T. Pegmatite-type gem deposits in China. Depos. Geology. 1996, 15, 9-16. (In Chinese)

79. Zou, T. Types and main producing areas of gemstones and mineral deposits in China. Depos. Geology. 1996, 15, 1-8. (In Chinese)

80. Wu, J.; Lu, S.; Zhang, Y.; Wang, H.; Li, Y. Geological conditions and prospecting direction of gem mineralization in Hebei Province. Miner. Resour. Geol. 2011, 25, 519-528. (In Chinese)

81. Zhang, C. Study on Mineralogical Characteristics of Blue Opals in Lishui, Zhejiang. Master's Thesis, China University of Geosciences, Beijing, China, 2018. (In Chinese with English Abstract)

82. Yan, J.; Hu, X.; Fang, B.; Tao, J.; Peng, Q.; Zhang, J. Study on mineralogical and optical characteristics of blue opals in Lishui by XRF-SEM-XRD-FTIR and other analysis and testing techniques. Rock Ore Testing. 2014, 33, 795-801. (In Chinese)

83. Huang, G.; Zhang, Y.; Cheng, H. A study of regional metallogenic regularity and prospecting direction of fluorite deposits in Zhejiang Province. Miner. Deposits 2015, 34, 1209-1222. (In Chinese with English Abstract)

84. Song, J. The Analysis of the Gemological and Chemical Characteristics of Fluorite in the Region from Checun to Heyu, Songxian County, Henan Province. World Nonferrous Met. 2019, 16, 119-121. (In Chinese with English Abstract)

85. Zeng, X. The Study on Gemological and Mineralogical Characteristics of Fluorite in Wuyi, Zhejiang. Master's Thesis, China University of Geosciences, Beijing, China, 2019. (In Chinese with English Abstract)

86. Zhang, Y. Gemological and Mineralogical Study of Malachites in the Oxidation Zone of Copper Deposits in the Azurite Hole in Yanqing. Master's Thesis, China University of Geosciences, Beijing, China, 2011. (In Chinese with English Abstract)

87. Li, H. Purple spodumene. Jewel. Technol. 2001, 1, 48-50. (In Chinese)

88. Qiu, C. Study on Mineralogical Characteristics of the Spodumene in the Altay Orogen, Xinjiang. Master's Thesis, China University of Geosciences, Beijing, China, 2014. (In Chinese with English Abstract)

89. Zhang, J.; Yu, X.; Li, Y. Minerogenic Prospective Prognosis of Leaching Type Turquoise on the Northwestern Margin of Wudang Uplift. Geophys. Geochem. Exploration 2019, 43, 273-280. (In Chinese with English Abstract)

90. Li, Z. Mineralogical Characteristics and Spectral Characterization of Turquoise from Maanshan, Anhui Province. Master's Thesis, China University of Geosciences, Beijing, China, 2019. (In Chinese with English Abstract) [CrossRef]

91. Huang, X. Mineralization Characteristics and Prospecting Direction of Turquoise Deposits. China Non-metallic Mineral Industry Guide. Chem. Doc. 2003, 6, 50-51. (In Chinese)

92. Tang, B.; Huang, W.; Li, C. Present Situation, Problems and Suggestions of Turquoise Industry in Hubei Province. Resources Environment \& Engineering. Chem. Doc. 2018, 32, 489-493. (In Chinese with English Abstract)

93. Shen, C. Study on the Genesis of Typical Deposits in Maanshan Turquoise Metallogenic Belt of Ningwu Basin. Ph.D. Thesis, China University of Geosciences, Beijing, China, 2020. (In Chinese with English Abstract)

94. Liu, L. Study on Origin, Factors and Grading of the Color of Turquoise from China. Master's Thesis, China University of Geosciences, Beijing, China, 2018. (In Chinese with English Abstract)

95. Chen, Q.; Yin, Z.; Qi, L.; Xiong, Y. Turquoise from Zhushan county, Hubei province, China. Gems Gemol. 2012, 48, 198-204. [CrossRef] 
96. Liu, L.; Yang, M.; Li, Y. Unique Raindrop Pattern of Turquoise from Hubei, China. Gems Gemol. 2020, 56, 380-400. [CrossRef]

97. Liu, L.; Yang, M.; Lu, R.; Shen, X.; He, C. Study on EDXRF Method of Turquoise Composition. Spectroscopy and Spectral Analysis. Chem. Doc. 2018, 38, 1910-1916. (In Chinese with English Abstract)

98. Sun, K. Geological characteristics of mineralization of gems in Yunnan. Geol. Yunnan. 1996, 1, 81-90. (In Chinese)

99. Zhang, J. Study on Characteristics and Color-Causing Factors of Taiwan Blue Chalcedony. Master's Thesis, Guilin University of Technology, Guilin, China, 2012. (In Chinese with English Abstract)

100. Liu, X.; Qian, J.; Chen, S. A new kind of jade-Chalcedony from Longling, Yunnan. Miner. Resour. Geol. 2013, 27, 162-168. (In Chinese)

101. Xu, W.; Xu, X.; Yang, L.; Wu, H. Geological characteristics and genesis analysis of "Warring States Red" agate deposits in Xuanhua, Hebei. Gems Gemol. 2017, 19, 1-11. (In Chinese with English Abstract)

102. Ding, W.; An, Z.; Chen, X.; Zhong, Y. Gemological characteristics and color-causes of rhodonites in Changping, Beijing. J. Beijing Polytech. College. 2013, 12,11-15. (In Chinese with English Abstract)

103. Li, K. Geological, technological properties and genesis of rhonodite deposits in Shang County, Shaanxi. Shaanxi Geol. 1992, 2, 23-30. (In Chinese)

104. Liu, Y.; Deng, J.; Shi, G.; Yui, T.-F.; Zhang, G.; Abuduwayiti, M.; Yang, L.; Sun, X. Geochemistry and petrology of nephrite from Alamas, Xinjiang, NW China. J. Asian Earth Sci. 2011, 42, 440-451. [CrossRef]

105. Yin, Z.; Jiang, C.; Santosh, M.; Chen, Y.; Bao, Y.; Chen, Q. Nephrite Jade from Guangxi Province, China. Gems Gemol. 2014, 50, 228-235. [CrossRef]

106. Wang, M.; Shi, G. The Evolution of Chinese Jade Carving Craftmanship. Gems Gemol. 2020, 56, 30-53. [CrossRef]

107. Yui, T.-F.; Usuki, T.; Chen, C.-Y.; Ishida, A.; Sano, Y.; Suga, K.; Iizuka, Y.; Chen, C.-T. Dating thin zircon rims by NanoSIMS: The Fengtien nephrite (Taiwan) is the youngest jade on Earth. Int. Geol. Rev. 2014, 56, 1932-1944. [CrossRef]

108. Ling, X.-X.; Schmädicke, E.; Li, Q.; Gose, J.; Wu, R.-H.; Wang, S.-Q.; Liu, Y.; Tang, G.-Q.; Li, X.-H. Age determination of nephrite by in-situ SIMS U-Pb dating syngenetic titanite: A case study of the nephrite deposit from Luanchuan, Henan, China. Lithos 2015, 220-223, 289-299. [CrossRef]

109. Gao, K.; Shi, G.; Wang, M.; Xie, G.; Wang, J.; Zhang, X.; Fang, T.; Lei, W.; Liu, Y. The Tashisayi nephrite deposit from South Altyn Tagh, Xinjiang, northwest China. Geosci. Front. 2018, 10, 1597-1612. [CrossRef]

110. Zhong, Q.; Liao, Z.; Qi, L.; Zhou, Z. Black Nephrite Jade from Guangxi, Southern China. Gems Gemol. 2019, 55, 198-215. [CrossRef]

111. Gil, G.; Bagiński, B.; Gunia, P.; Madej, S.; Sachanbiński, M.; Jokubauskas, P.; Belka, Z. Comparative Fe and Sr isotope study of nephrite deposits hosted in dolomitic marbles and serpentinites from the Sudetes, SW Poland: Implications for Fe-As-Au-bearing skarn formation and post-obduction evolution of the oceanic lithosphere. Ore Geol. Rev. 2020, 118. [CrossRef]

112. Harlow, G.E.; Sorensen, S.S.; Sisson, V.B.; Shi, G. Chapter 10: The Geology of Jade Deposits. In The Geology of Gem Deposits, 2nd ed.; Lee, A.G., Ed.; Short Course Handbook Series 44; Mineralogical Association of Canada: Quebec, QC, Canada, 2014; pp. 305-374.

113. Harlow, G.E.; Sorensen, S.S. Jade (nephrite and jadeitite) and serpentinite: Metasomatic connections. Int. Geol. Rev. 2005, 47, 113-146. [CrossRef]

114. Liu, Y.; Deng, J.; Shi, G.; Sun, X.; Yang, L. Geochemistry and petrogenesis of placer nephrite from Hetian, Xinjiang, Northwest China. Ore Geol. Rev. 2011, 41, 122-132. [CrossRef]

115. Liu, Y.; Zhang, R.; Zhang, Z.; Shi, G.; Zhang, Q.; Anuduwayiti, M.; Liu, J. Mineral inclusions and SHRIMP U-Pb dating of zircons from the Alamas nephrite and granodiorite: Implications for the genesis of a magnesian skarn deposit. Lithos 2015, 212-215, 128-144. [CrossRef]

116. Wang, S.; Dong, P. Classification, geologic characteristics and origin of the jade from Xiuyan, Liaoning province, China. Geol. Resour. 2011, 20, 311-321. (In Chinese with English Abstract)

117. Chen, J. A cheap and good serpentine jade. Jewelry Technology. Chem. Doc. 2001, 2, 20-21. (In Chinese)

118. Zhou, T. On the origin of Qilian jade-a case of Huilanggou, Caka. Qinghai Geology 1993, 2, 8-16. (In Chinese with English Abstract)

119. Chen, C. Practice and Thinking of the Seal Stone Carving. Tiangong 2021, 1, 84-85. (In Chinese)

120. Yuan, Y.; Shi, G.; Lou, F.; Shi, M. Mineralization and Metallogenic Model of China's Seal Stone Deposits. J. Petro Mineralogy 2014, 33, 146-152. (In Chinese with English Abstract) 